\title{
Associations between Ectomycorrhizal Fungi and Bacterial Needle Endophytes in Pinus radiata: Implications for Biotic Selection of Microbial Communities
}

\author{
Megan A. Rúa ${ }^{1,2 *}$, Emily C. Wilson ${ }^{3}$, Sarah Steele ${ }^{1}$, Arielle R. Munters ${ }^{3}$, \\ Jason D. Hoeksema ${ }^{1}$ and Anna C. Frank ${ }^{3}$
}

${ }^{1}$ Department of Biology, University of Mississippi, Oxford, MS, USA, ${ }^{2}$ National Institute for Mathematical and Biological Synthesis, University of Tennessee, Knoxville, TN, USA, ${ }^{3}$ Life and Environmental Sciences and Sierra Nevada Research Institute, School of Natural Sciences, University of California, Merced, Merced, CA, USA

OPEN ACCESS

Edited by:

M. Pilar Francino,

FISABIO Public Health, Valencian

Health Department, Spain

Reviewed by:

Pepijn Wilhelmus Kooij,

Royal Botanic Gardens, Kew, UK

Frank O'Neill Aylward,

University of Hawaii, USA

${ }^{*}$ Correspondence:

Megan A. Rúa

megan.rua@nimbios.org

Specialty section:

This article was submitted to

Microbial Symbioses,

a section of the journal

Frontiers in Microbiology

Received: 25 November 2015 Accepted: 14 March 2016 Published: 31 March 2016

Citation:

Rúa MA, Wilson EC, Steele $S$,

Munters AR, Hoeksema JD and Frank AC (2016) Associations

between Ectomycorrhizal Fungi and Bacterial Needle Endophytes in Pinus radiata: Implications for Biotic Selection of Microbial Communities.

Front. Microbiol. 7:399.

doi: 10.3389/fmicb.2016.00399
Studies of the ecological and evolutionary relationships between plants and their associated microbes have long been focused on single microbes, or single microbial guilds, but in reality, plants associate with a diverse array of microbes from a varied set of guilds. As such, multitrophic interactions among plant-associated microbes from multiple guilds represent an area of developing research, and can reveal how complex microbial communities are structured around plants. Interactions between coniferous plants and their associated microbes provide a good model system for such studies, as conifers host a suite of microorganisms including mutualistic ectomycorrhizal (ECM) fungi and foliar bacterial endophytes. To investigate the potential role ECM fungi play in structuring foliar bacterial endophyte communities, we sampled three isolated, native populations of Monterey pine (Pinus radiata), and used constrained analysis of principal coordinates to relate the community matrices of the ECM fungi and bacterial endophytes. Our results suggest that ECM fungi may be important factors for explaining variation in bacterial endophyte communities but this effect is influenced by population and environmental characteristics, emphasizing the potential importance of other factors - biotic or abiotic - in determining the composition of bacterial communities. We also classified ECM fungi into categories based on known fungal traits associated with substrate exploration and nutrient mobilization strategies since variation in these traits allows the fungi to acquire nutrients across a wide range of abiotic conditions and may influence the outcome of multi-species interactions. Across populations and environmental factors, none of the traits associated with fungal foraging strategy types significantly structured bacterial assemblages, suggesting these ECM fungal traits are not important for understanding endophyte-ECM interactions. Overall, our results suggest that both biotic species interactions and environmental filtering are important for structuring microbial communities but emphasize the need for more research into these interactions.

Keywords: 16S rRNA, bacterial endophytes, conifers, exploration types, foraging traits, Gammaproteobacteria, soil texture 


\section{INTRODUCTION}

All plants associate with a diverse array of microorganisms throughout their tissues, but microbes associated with above- and belowground portions of plants are typically studied separately. However, a growing body of research indicates that aboveand belowground multitrophic interactions have important implications for both plant community structure and ecosystem function (Wardle et al., 2004; Van Der Putten, 2009; Wagg et al., 2011; Rúa et al., 2013). Such interactions are intrinsically linked for plant-associated microbes since many microbes may have physiological effects on plant performance that span the entirety of the plant (as opposed to localized to the direct area they occupy); therefore, plant-associated microbes may play an important role in the structure and dynamics of one another, even if they occupy spaces within the tree that are a significant distance from one another. Furthermore, our knowledge concerning the ecology and interactions of microbes in plants is likely biased because studies of plant-microbial interactions are commonly based on controlled, optimized conditions for growth of host plants and seldom based on variable, field-realistic conditions. In addition, the degree to which non-wild and wild systems are comparable for plant-microbe interactions remains unclear as there are major differences in both phylogenetic diversity and species composition of plant hosts between agroecosystems and the associated forest regions (Griffin and Carson, 2015).

Coniferous plants and their associated microbes provide a good model system for exploring the interaction of above- and belowground plant-associated microbes as conifers interact with a suite of microorganisms including mutualistic mycorrhizal fungi (Smith and Read, 2008), pathogenic eukaryotic microbes (Fogel, 1988), and foliar bacterial and fungal endophytes (Carroll, 1988; Pirttilä et al., 2005; Arnold et al., 2007; Carrell and Frank, 2014, 2015; Oono et al., 2014). The relationships between conifers and their microbes may be particularly important since conifers grow in impoverished acidic soils at both mid and high latitudes, potentially facilitated by their relationship with various microbes (Axelrod, 1986; Lepage et al., 1997; Richardson, 2000; Carrell and Frank, 2014).

The nutritional mutualism between mycorrhizal fungi and plants is a key component of a conifer's ecological niche, as the two organisms are believed to have co-diversified approximately 200 million years ago and now form functionally obligate associations (Smith and Read, 2008; Tedersoo et al., 2010). These relationships are characterized by the exchange of carbon (C) in the form of carbohydrates from the plant for mineral nutrients such as nitrogen $(\mathrm{N})$, phosphorus $(\mathrm{P})$, and micronutrients supplied by the fungi (Smith and Read, 2008). Conifers associate primarily with ectomycorrhizal (ECM) fungi, an extremely diverse group that contains more than 5,000 described species from the fungal order Agaricales alone (Ryberg and Matheny, 2012). ECM fungi are particularly important for conifers as they improve plant growth and confer resistance against biotic and abiotic stresses (Smith and Read, 2008). The degree to which ECM fungi are able to confer such resistance is likely related to their ability to forage the litter and mineral layers for nutrients (Agerer, 2001; Selosse et al., 2006; Anderson and Cairney, 2007; Hobbie and Agerer, 2010). The extramatrical mycelium, which extends out into the soil from ECM root tips and facilitates nutrient uptake and transport, has evolved distinct characteristics in different taxa of ECM fungi related to their ability to acquire nutrients. These characteristics include mycelial growth pattern, extent of biomass accumulation, hydrophobicity of the hyphae, and the presence or absence of rhizomorphs (linear aggregations of paralleloriented hyphae) are used to classify fungi into exploration types. These exploration types reflect differences among taxa in exploration and nutrient mobilization strategy such that variation in these traits allows the fungi to acquire nutrients across a wide range of abiotic conditions (Agerer, 2001; Hobbie and Agerer, 2010; Lilleskov et al., 2011). For example, mediumdistance fringe and long-distance exploration types have the potential to explore recalcitrant nutrient pools while species with contact, short, and medium-distance smooth exploration types tend to be associated with labile nutrient soil pools (Lilleskov et al., 2002; Hobbie and Agerer, 2010). While these characteristics primarily provide resistance to abiotic stresses, they are also likely to confer resistance to biotic stresses, particularly by increasing a plant's overall tolerance to stress. Using a trait-based approach to ECM fungal ecology has been an important tool for studying the effect of ECM on ecosystem processes such as nitrogen and carbon cycling (Krause et al., 2014; AguilarTrigueros et al., 2015), but it may also provide an important framework to link ECM diversity to species interactions with other microorganisms.

Although belowground plant-associated microbial communities have received extensive attention (Bever, 2003; Van Der Heijden et al., 2008; van der Putten et al., 2013), their aboveground counterparts remain an area of developing research. The study of endophytes (microorganisms that spend at least part of their life cycle inside plants), has traditionally focused on fungi that live inside the aboveground portion of plants (Schardl and Phillips, 1997; Six et al., 2006). In contrast, knowledge of the role of aboveground bacterial endophytes in plant growth, plant nutrient uptake, and protection against biotic and abiotic stress in wild plants is growing (Chanway, 1996).

The needles of conifers are heavily colonized by fungal endophytes (Pirttilä and Wäli, 2009), and the number of infections typically increases with needle age and varies with position such that needles and buds tend to differ in their fungal endophyte communities. Less is known about the endophytic bacteria in conifer foliage and their ecological interactions with plants. Recent $16 \mathrm{~S}$ rRNA surveys of the endophytic community in high elevation pines suggest that these trees select specific taxa that recur within and between Pinus species growing in the subalpine environment (Carrell and Frank, 2014). The foliar endophyte communities of coast redwood and giant sequoia are more variable and diverse, but clearly select for specific bacterial lineages that are also shared with other wild plants (and lichens) (Carrell and Frank, 2015). Indeed, conifer-bacteria interactions can be very intimate, as illustrated by the plant growth promoting bacterial endophyte Methylobacterium extorquens DSM 1360, which occupies a niche within the plant cell in association with the nucleus (Koskimäki et al., 2015). 
Evidence from agricultural crop species and Arabidopsis thaliana suggests that bacterial endophyte communities are structured based on C usage (Ji and Wilson, 2002; Innerebner et al., 2011), but structuring factors are less understood in wild plants. Additional research suggests that foliar bacterial endophytes may serve an important role as $\mathrm{N}_{2}$ fixers for a wide taxonomic range of plants including conifers (James, 2000; Carrell and Frank, 2014; Chanway et al., 2014), and incorporation of fixed $\mathrm{N}$ by the plant host has been demonstrated in several systems (Sevilla et al., 2001; Pankievicz et al., 2015). Consequently, environmental factors that alter plant nutrient acquisition, including nutritional relationships with other microbial symbionts such as ECM fungi, may be important for structuring bacterial endophyte communities.

While studies examining the interaction of ECM fungi and bacterial endophytes are limited, recent laboratory work indicates that the outcome of the interaction between foliar bacterial endophytes and ECM fungi is dependent upon the identity of the fungus. In a highly controlled study examining the interaction of an ECM fungus (Pisolithus tinctorius or Suillus variegatus) and the bacterial pine endophyte $M$. extorquens DSM 1360 on the growth of Scots pine (Pinus sylvestris) seedlings, identity of the ECM fungi was important for determining the overall effect of the interaction. Specifically, seedlings inoculated with $P$. tinctorius and $M$. extorquens, had greater overall biomass than those grown without microbes or with only one microbe (Pohjanen et al., 2014). In contrast, seedlings inoculated with S. variegatus and $M$. extorquens were larger than the non-microbe control but did not differ in overall biomass from those inoculated with only a single microbe (Pohjanen et al., 2014). This study, while limited to one bacterial species, suggests fungal identity is an important factor in determining the outcome of ECM-bacterial endophyte interactions in pines and suggests belowground ECM fungal communities have the potential to structure aboveground bacterial endophytes; however, in order to more fully understand the interaction of ECM fungi and bacterial endophytes, research that evaluates diverse, natural ECM fungal communities and bacterial endophytes in adult trees is necessary.

In our study, we investigate the extent to which the belowground ECM fungal community of a conifer is associated with its aboveground foliar bacterial endophyte communities, and whether host population and environmental characteristics alter this relationship. We focused on Monterey Pine (Pinus radiata D. Don), a locally dominant conifer with a native range that consists of small isolated populations spanning a broad latitudinal gradient along the west coast of California and Mexico (Grotkopp et al., 2004). Previous work with $P$. radiata indicates that different populations harbor different ECM fungal communities, at least in part due to genetic differences among host populations (Hoeksema and Thompson, 2007; Hoeksema et al., 2012) but to our knowledge, their foliar bacterial endophytes have never been characterized. Via molecular methods, we identified ECM fungal communities (ITS-1F and ITS4) and foliar bacterial endophytes (16S rRNA) for three isolated populations of $P$. radiata in California (Año Nuevo, Monterey, and Cambria). We then used multivariate modeling approaches to explore the extent to which population and environmental factors shaped ECM and endophyte communities independently, how the microbe communities related to one another, and whether these patterns were influenced by either population or environmental characteristics.

\section{MATERIALS AND METHODS}

\section{Description of Field Site and Field Sampling Methods}

Soil and foliage were collected from stands in three native Monterey pine populations in mainland California: Swanton

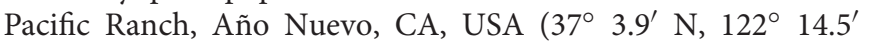
W), Point Lobos State Natural Reserve, Monterey, CA, USA $\left(36^{\circ}\right.$ $\left.30.9^{\prime} \mathrm{N}, 121^{\circ} 56.6^{\prime} \mathrm{W}\right)$ and at the Kenneth S. Norris Rancho Marino Reserve, Cambria, CA, USA ( $\left.35^{\circ} 32.2^{\prime} \mathrm{N}, 121^{\circ} 04.7^{\prime} \mathrm{W}\right)$. Monterey pine was the dominant ECM tree species at all three sampling sites, although occasional Douglas-firs (Pseudotsuga menziesii) were observed at Año Nuevo, and occasional coast live oaks (Quercus agrifolia) were observed at both Cambria and Año Nuevo. In addition, knobcone pine (Pinus attenuata) is known to occur in the Año Nuevo population and to hybridize with Monterey pine, but no knobcone pines were observed in the vicinity of our specific sampling site.

Between February 21-23, 2014 we sampled five haphazardly chosen trees at each site that were similar in size as determined by diameter at breast height $(\mathrm{DBH})$. The distance between the two farthest spaced trees at each site varied from $0.14 \mathrm{~km}$ (at Monterey and Cambria) to $1.67 \mathrm{~km}$ (at Año Nuevo). Power analyses that were undertaken prior to sampling suggested that five trees per site would be adequate to detect the patterns we were interested in exploring. Soil was obtained by collecting four cores per tree per site (total 20 cores), each $10 \mathrm{~cm}$ in diameter and $20 \mathrm{~cm}$ deep (excluding litter) from four locations chosen in each cardinal direction within $1 \mathrm{~m}$ around a focal tree to obtain a representative sample of each tree. Soil samples were stored in insulated coolers, overnighted to the laboratory at the University of Mississippi, stored at $4^{\circ} \mathrm{C}$, and processed within 17 days of collection. All root samples and surrounding soil were kept intact until processing.

Needle and bud tissue samples were collected from each of the five trees per site. Five to ten small needle bundles were collected from each tree, at the North, South, East, and West sides of the tree to obtain a representative sampling at approximately $2 \mathrm{~m}$ height. Buds were collected when present and pooled by site. Samples were collected with sterile gloves and blades, and large sterile sample bags were used to minimize tissue damage. Samples were stored in cool conditions for transport back to the lab for surface sterilization within 1 week of sampling.

\section{Bacterial Sequencing and OTU Generation}

\section{Sample Sterilization}

All foliage samples were processed at UC Merced. Foliage was sterilized by submersion in 30\% hydrogen peroxide for $1 \mathrm{~min}$ followed by 10, 1 min shaking rinses in ultrapure water and stored at $-20^{\circ} \mathrm{C}$. Sterility was confirmed by negative PCR amplification 
of the final rinse. Negative PCR amplification of the final rinse suggests sterility; however, microscopy would be necessary to verify sterility. Thus, it is possible that some of the bacterial taxa we observe are epiphytes.

\section{DNA Extraction for Bacterial Analysis}

Foliage samples were ground to a fine powder with a sterile mortar and pestle on a liquid nitrogen filled-base. DNA was extracted using a CTAB extraction method as described previously (Carrell and Frank, 2014). Briefly, $800 \mu \mathrm{L}$ of CTAB solution (1 mL CTAB buffer, $0.04 \mathrm{~g}$ of polyvinylpyrrolidone, $5 \mu \mathrm{L}$ of 2-mercaptoethanol) was added to $0.6 \mathrm{~g}$ of tissue, incubated for $2 \mathrm{~h}$ at $60^{\circ} \mathrm{C}$, and homogenized with sterile glass beads for $3 \mathrm{~min}$. Proteins were removed with the addition of an equal volume of 24:1 molecular grade chloroform/isoamyl alcohol, centrifuged for $10 \mathrm{~min}$ at $16 \mathrm{rcf}$, and the top aqueous phase was placed in a sterile tube. Nucleic acids were precipitated with the addition of $1 / 10$ volume of cold $3 \mathrm{M}$ sodium acetate and $1 / 1$ volume cold isopropanol, placed in a $-20^{\circ} \mathrm{C}$ freezer for $12 \mathrm{~h}$, followed by centrifugation for $30 \mathrm{~min}$ at $16 \mathrm{rcf}$ to pellet the DNA. The supernatant was removed, $700 \mu \mathrm{L}$ of $70 \%$ ethanol was added, then the tube was shaken to dislodge and rinse the pellet, followed by centrifugation for $10 \mathrm{~min}$. The ethanol was then removed and the pellet was air dried in sterile conditions. The air-dried pellet was re-suspended with $30 \mu \mathrm{L}$ of DNA suspension buffer $(1.0 \mathrm{M}$ Tris-HCL, 0.1 M EDTA) and stored at $-20^{\circ} \mathrm{C}$.

\section{DNA Amplification for Bacterial Analysis}

The 16S rRNA genes of endophytic bacteria were amplified using nested PCR to reduce the occurrence of plastid sequences and improve consistency. Plant DNA amplification was suppressed with the primer pair 16S 799f (AACMGGATTAGATACCCKG) and 16S 1492r (TACGGHTACCTTGTTACGACT) in the first PCR reaction (PCR1). Amplification with 16S 799f and 16S 1492r result in mitochondrial amplicon of about $1000 \mathrm{bp}$ and bacterial amplicon of about $750 \mathrm{bp}$ (Chelius and Triplett, 2001). In the final round of PCR (PCR2), an appropriate amplicon length for Illumina sequences was achieved from PCR1 amplicons with the Illumina adapted, Golay-barcoded primer pair 799f and 1115r (AGGGTTGCGCTCGTTG), an optimized primer set for phylogenetic analysis of short reads (Redford et al., 2010) reduced primer bias by decreasing the number of cycles (Jiao et al., 2006) with the following thermocycle profile used for PCR1 and PCR2: one cycle of $3 \mathrm{~min}$ at $95^{\circ} \mathrm{C} ; 20$ cycles of $40 \mathrm{~s}$ at $95^{\circ} \mathrm{C}, 40 \mathrm{~s}$ at $50^{\circ} \mathrm{C}, 1.5 \mathrm{~min}$ at $72^{\circ} \mathrm{C}$; and a final $10 \mathrm{~min}$ of elongation at $72^{\circ} \mathrm{C}$. The $50 \mu \mathrm{L}$ PCR 1 reaction contained $5 \mu \mathrm{L}$ of DNA extract, $20 \mu \mathrm{L} 5$ PRIME Hot Master Mix (5 PRIME, Inc.), $0.5 \mu \mathrm{g} / \mu \mathrm{l}$ Bovine Serum Albumin (Thermo Scientific), $21.5 \mu \mathrm{L}$ PCR grade water (Fisher BioReagents), and $0.2 \mu \mathrm{M}$ of forward and reverse primers. The $25 \mu \mathrm{L}$ PCR2 reaction contained $3 \mu \mathrm{L}$ of PCR1 product, $10 \mu \mathrm{L} 5$ PRIME Hot Master Mix, $0.5 \mu \mathrm{g} / \mu \mathrm{L}$ Bovine Serum Albumin (Thermo Scientific), $8.75 \mu \mathrm{L}$ PCR grade water (Fisher BioReagents), and $0.2 \mu \mathrm{M}$ of forward and reverse primers. PCR2 amplicons were then cleaned, pooled, and gel extracted (QIAquick Gel Extraction Kit) to ensure selection of the correct band size and to remove most mitochondrial products. Pooled samples were then submitted for Illumina sequencing at the University of California, Davis Genome Center.

\section{OTU Generation and Classification for Bacterial Analysis}

Sequences were analyzed and processed using the QIIME (1.8.0) package (Caporaso et al., 2010b), but with the UPARSE method for clustering operational taxonomic units (OTUs) (Edgar, 2013). Forward and reverse paired-end reads were joined with fastq-join, with the barcode filtered from the dataset if the forward and reverse read did not overlap (Aronesty, 2011). Joined pair-end reads were quality filtered with QIIME defaults settings (maximum number of consecutive low quality base calls of three bases; minimum number of consecutive high quality base calls as a fraction of the input read length of 0.5 total read length; maximum unacceptable Phred quality score of 3 ; no $\mathrm{N}$ characters) which have been found to sufficient for community analysis (Bokulich et al., 2013). The remaining sequences were clustered into OTUs at the 97\% level. Representative sequences were aligned using PyNAST (Caporaso et al., 2010a) against the Greengenes core set (DeSantis et al., 2006). Taxonomic assignments were made using uclust (Edgar, 2010) with the Greengenes representative set of sequences as reference. Sequences classified as "Chloroplast," "Mitochondria" or "Unassigned" were removed. An approximately maximum-likelihood tree was constructed from an alignment of representative sequences, using FastTree (Price et al., 2009).

\section{Fungal Sequencing and OTU Generation Laboratory Processing of Root Samples and Morphotyping}

Roots were hand washed over a $2 \mathrm{~mm}$ sieve to remove rhizosphere soil. All roots within a sample were pooled and the root-tip region encompassed by the fungal hartig net of the ECM fungi was assessed using a dissecting microscope. The number of root tips with viable ECM fungal colonization was counted, and each root tip was classified into a morphotype based on morphological distinctions such as color, texture, branching patterns, and emanating hyphae or rhizomorphs. Two root tips per morphotype observed in each sample were removed for identification via Sanger sequencing. All laboratory processing of root samples and morphotyping occurred within 17 days of collection.

\section{DNA Extraction and Sequencing}

After morphotyping, DNA was immediately extracted from root tips from each sample using components of a Sigma Extract-NAmp extraction kit (Sigma-Aldrich, St. Louis, MO, USA). Ten microliter of the Sigma Extraction Buffer was added to each root tip, which was heated to $65^{\circ} \mathrm{C}$ for $10 \mathrm{~min}, 95^{\circ} \mathrm{C}$ for $10 \mathrm{~min}$, and then received $30 \mu \mathrm{L}$ of Sigma Neutralization Solution and $60 \mu \mathrm{L}$ PCR-grade water. Samples were then stored at $-20^{\circ} \mathrm{C}$ for approximately 1 month.

To facilitate Sanger sequencing of ECM fungal species colonizing root tips, the Internal Transcribed Spacer (ITS) region 
of the fungal nuclear genome was amplified using the fungalspecific forward and reverse primers, ITS1F and ITS4 (Gardes and Bruns, 1993). Amplification was achieved according to the protocol outlined in Rúa et al. (2015) and success was checked on a $1 \%$ agarose gel with SYBR ${ }^{\circledR}$ Safe DNA gel stain (Molecular Probes, Eugene, OR, USA). Approximately 10\% of samples did not amplify with the default settings. The raw DNA for these samples was diluted to $1 \%$ DNA $(1 \mu 1 \mathrm{DNA}+99 \mu 1$ sterile PCRgrade water) and amplification reactions were repeated using the same methods as the default except that the number of cycles for denaturation, annealing, and extension was increased from 35 cycles to 40 cycles. Approximately 5\% of dilutions did not amplify with these settings so amplification was repeated with the same methods as the previous dilutions and the annealing temperature was lowered from $52^{\circ} \mathrm{C}$ to $51^{\circ} \mathrm{C}$.

Excess primer and unincorporated nucleotides were removed enzymatically using the Exonuclease I (ExoI) and Antarctic Phosphotase (AP) enzymes (New England BioLabs, Inc., Ipswich, MA, USA) with the following procedure: $0.5 \mu \mathrm{l}$ ExoI, $0.5 \mu \mathrm{l} \mathrm{AP}$, and $4.5 \mu \mathrm{l}$ sterile PCR-grade water were added to $5 \mu \mathrm{l}$ of the PCR product and incubated at $37^{\circ} \mathrm{C}$ for $45 \mathrm{~min}$, then $80^{\circ} \mathrm{C}$ for $20 \mathrm{~min}$, and finally $4^{\circ} \mathrm{C}$ for at least $5 \mathrm{~min}$.

Sequencing was performed using the forward primer ITS5 (Gardes and Bruns, 1993) and the Big Dye Terminator Sequencing Kit (v3.1, Invitrogen Corp.). Each Big Dye reaction contained $0.4 \mu \mathrm{L}$ Big Dye Reaction Premix, $1.8 \mu \mathrm{L}$ Big Dye $5 \mathrm{X}$ sequencing buffer, $0.5 \mu \mathrm{L}$ of the forward primer at $10 \mu \mathrm{M}$ concentration, $6.3 \mu \mathrm{L}$ of PCR-grade water, and $1 \mu \mathrm{L}$ of the cleaned PCR product. Amplification conditions were $96^{\circ} \mathrm{C}$ for $1 \mathrm{~min}$; followed by 35 cycles of $95^{\circ} \mathrm{C}$ for $30 \mathrm{~s}, 50^{\circ} \mathrm{C}$ for $20 \mathrm{~s}$, and $60^{\circ} \mathrm{C}$ for $4 \mathrm{~min}$. Reactions were dried and shipped overnight to the DNA Lab at Arizona State University, in Tempe, AZ, USA, where the Big Dye reactions were purified and read on an Applied Bioscience 3730 capillary genetic analyzer. We chose to sequence the fungal samples in one direction as this approach provides plenty of high-quality sequences of sufficient length for OTU assembly and taxonomic matching while keeping costs low. The main effect of only sequencing in one direction is to modestly lower the quality of some sequences, but this should not bias the results in a meaningful way, except perhaps to increase the number of singlet OTUs.

\section{Sequence Assignment}

The fungal DNA sequences obtained were edited manually in Geneious software (Biomatter Ltd.), correcting ambiguous bases associated with dye blobs and elsewhere when possible. All sequences with $>3 \%$ ambiguous bases or $<200$ base pairs long were deleted. Remaining sequences were subjected to OTU assembly (at 97\% similarity) using CAP3 software (Huang and Madan, 1999) on the University of Alaska, Fairbanks (UAF) Life Science Informatics server, using default settings except the following: maximum overhang percent length $=60$, match score factor $=6$, overlap percent identity cut-off $=97$, clipping range $=6$, as described previously in (Rúa et al., 2015). Grouping homologous sequences that are $>97 \%$ similar as a specific OTU is a conservative approach employed by previous studies (Izzo et al., 2005; O’Brien et al., 2005; Smith et al., 2007) and assumes a $0.2-1.2 \%$ error rate produced by PCR and unidirectional sequencing, as well as $\sim 1.5 \%$ divergence of the ITS region that may occur within some species at small spatial scales (Horton, 2002).

Consensus fungal sequences from each OTU were checked using BLAST (Altschul et al., 1990; nucleotide) searches on the International Nucleotide Sequence Database (INSD) and the User-Friendly Nordic ITS Ectomycorrhizal (UNITE) database (Kõljalg et al., 2013) to obtain best matches for taxonomic affiliation of OTUs. The ultimate decision on the best match to a sequence was based on both similarity and length of the match. Sequences $>97 \%$ similar in composition to database sequences from named, cultured fungi were considered the same OTU (hereafter, 'species'). Sequences with matches showing 94-97\% similarity to a database sequence with an assigned species epithet, or matching a sequence identified only to genus were assigned into the respective genus and assigned a number (e.g., Russula 1). Similarly, those matches in the database $<94 \%$, but greater than $90 \%$ were assigned to the appropriate taxonomic family. Any matches $<90 \%$ similar to database sequences were left out of the analyses. If sequence matches among the two sequence repositories showed equal affinity or similarity to multiple genera within a family, priority was given to the vouchered specimens residing on the UNITE or curated fungal ITS databases. Any species known to be strictly pathogenic was eliminated from the data set.

When fungal OTUs could be identified to species, fungal traits associated with foraging strategy, foraging distance, rhizomorph formation, and hydrophobicity (Agerer, 2001), were assigned using the Determination of EctoMYcorrhiza database (DEEMY, http://www.deemy.de). Since foraging related functional traits are typically conserved at the genus level (Agerer, 2006), when no species-level matches were available in DEEMY, entries for congeners associated with Pinus were surveyed. Consensus trait values were assigned if $90 \%$ of entries agreed which allowed for data that could only be identified to genus to be incorporated (sensu Moeller et al., 2014).

\section{Soil Characterization}

Soil texture (\% sand, \% silt, \% clay) was characterized for each soil sample (Lamotte soil texture test kit). Soil water content was determined as the ratio of the initial soil weight to the soil weight after being dried in a drying oven at $65^{\circ} \mathrm{C}$ for $72 \mathrm{~h}$.

\section{Statistical Analyses}

Before analyses fungal and bacterial data were pooled by tree, abundance of each ECM fungal species were relativized by the total abundance observed in the data set (McCune and Grace, 2002) in order to put all species abundances on the same relative scale. Bacterial OTUs were rarified to an even sampling depth of 7364 sequences (the smallest amount of sequences for any sample) and OTUs with greater than 100 observations were selected for further downstream analyses (R Core Team, 2015). After demultiplexing, quality control, OTU clustering, taxonomic identification and rarefaction using QIIME, version 1.8.0 and UPARSE as described above, the bacterial OTU table was exported into $\mathrm{R}$ using the phyloseq package for further 
analyses (McMurdie and Holmes, 2013). All subsequent analyses were done with R statistical software, version 3.1.3.

To assess variation in environmental factors due to population (site), each environmental factor (\% silt, \% sand, \% clay, soil water content) was subjected to a linear model using the $l m$ function from the stats package (R Core Team, 2015). All environmental factors were tested for normality and found to possess normal distributions. Differences between sites were determined with a Tukey's multiple comparison test using the HSD.test function from the agricolae package (de Mendiburu, 2014). Environmental variables were further subject to correlation analysis using the cor function of the stats package (R Core Team, 2015) and analyzed using principal components analysis (PCA) after centering and standardization of the variables using the prcomp function from the stats package (R Core Team, 2015). Visualizations for these analyses were created by adapting the ggbiplot function from the ggbiplot package $(\mathrm{Vu}, 2011)$ and using the ggplot2 package (Wickham, 2009). Percent silt and \% sand were found to be correlated (Table 1: $-0.7985, p<0.0001$ ) but when combined into a single metric, results were not qualitatively different then when left apart (see Supplementary Material). We briefly mention in the text the results obtained with the combined variable.

\section{Community Analysis}

Alpha diversity (the diversity within a single tree) was estimated using the Chaol index which measures species richness, and the Shannon diversity index which integrates richness and evenness. Both indices were calculated via functions in the vegan package (estimateR to calculate the Chaol index and diversity to calculate the Shannon index; Oksanen et al., 2015). Variation in richness and diversity among locations (beta diversity) was assessed using linear models with the $l m$ function and population as the predictor variable. To determine the frequency of different ECM fungal foraging strategies by population, we used Pearson's chisquared tests from the xtabs function in the stats package ( $\mathrm{R}$ Core Team, 2015). To determine if the distribution of traits associated with ECM fungal foraging strategy (response variable) changes as a result of the environmental characteristics (predictor variable), we used logistic regression via the $g l m$ function with poisson family and log link in the stats package (R Core Team, 2015).

To assess the sources of variation in the microbial community matrices due to population, environmental factors, fungal foraging strategy (ECM only), and tissue type (bacteria only) we used permutational manova based on 999 permutations and the Bray-Curtis method for calculating dissimilarity indices via the adonis function in the vegan package (Oksanen et al., 2015). Visualizations for this analysis were created using NMDS plots and the Bray-Curtis method via the metaMDS function in the vegan package and the ggplot2 package (Wickham, 2009). In order to determine if any fungal or bacterial species were driving patterns due to population or tissue type (bacteria), we calculated correlation indices with the mulitpatt function from the indicspecies package (De Cáceres and Legendre, 2009) and corrected the resulting phi coefficient for the fact that some species may be present at more sites then others (De Cáceres et al., 2010). Analyses were run with 1000 permutations. Because the environmental variables are continuous, in order to examine the role environmental variables played in influencing the abundance of microbes, we conducted correlation analyses between individual OTU abundances and single environmental variables with the cor function of the stats package (R Core Team, 2015).

We used constrained analysis of principal coordinates (CAP) which allows for the use of non-Euclidean dissimilarity indices, such as Jaccard or Bray-Curtis distance, to relate the community matrices of the ECM fungi and bacterial endophytes. First, matrices were restricted to those microbes that were identified from multiple trees within a population and from all populations (67 bacterial species and 5 fungal species). Because our bacterial species matrix was significantly larger than our fungal species matrix, we were able to explore the extent to which fungal species were associated with bacterial species, but could not explore the reverse question regarding the extent to which bacterial species can structure the fungal communities. To do this we utilized the capscale function from the vegan package to determine whether fungal species influenced the bacterial species community (Oksanen et al., 2015). This function performs a constrained ordination describing variation in the bacterial species community composition along defined axes - the composite variables representing fungal community composition - then proceeds to explain the remaining variation via unconstrained ordination (Oksanen et al., 2015). The resulting output was then subjected to Type I ANOVA with 999 permutations to determine which ECM fungal species were influencing the bacterial community. Subsequent models were run using the 'condition' option of capscale which removes variation from the designated variable from the ordination before constraining for other variables (a 'partial' CAP). Separate models were run that conditioned for population or environmental

TABLE 1 | Correlation coefficients and associated $p$-values for environmental variables.

\begin{tabular}{|c|c|c|c|c|c|c|c|}
\hline & \multicolumn{2}{|c|}{ Soil water content } & \multicolumn{2}{|c|}{$\%$ Clay } & \multicolumn{2}{|c|}{$\%$ Sand } & $\%$ Silt \\
\hline$\%$ Clay & 0.2950 & $0.0012^{* *}$ & 1.000 & & & & \\
\hline$\%$ Silt & -0.4200 & $<0.0001^{* * *}$ & -0.3529 & $<0.0001^{* * *}$ & -0.7985 & $<0.0001^{* * *}$ & 1.000 \\
\hline
\end{tabular}


variables. Finally, analyses were repeated using ECM fungal traits (rather than ECM species identity) to examine their influence in shaping the bacterial endophyte community. All analyses were initially run using Bray-Curtis distance but were repeated using Jaccard distances. Since analyses did not differ, we present analyses with Bray-Curtis distance here. Visualizations were created by modifying the autoplot function in ggvegan (Simpson, 2015).

\section{RESULTS}

\section{Environmental Characteristics}

Linear models indicate the three $P$. radiata populations differed significantly in several environmental factors (Supplementary Figure S1) including soil water content $\left(F_{2,15}=87.97\right.$, $p<0.0001)$ and all three measures of soil texture (\% silt: $F_{2,15}=163.8, p<0.0001, \%$ sand: $F_{2,15}=39.96, p<0.0001, \%$ clay: $\left.F_{2,15}=104.1, p<0.0001\right)$. Specifically, \% silt is highest for Monterey, \% clay is highest for Cambria, and Año Nuevo has higher \% sand and soil water content (Supplementary Figure S1). The correlation structure within the set of environmental variables was visualized using PCA (Supplementary Figure S2). The first two axes describe $83.8 \%$ of the total variation. Population was clearly related to the environmental variables. There was a negative correlation between $\%$ silt and \% sand $(-0.7984)$ but while the other environmental characteristics were significantly correlated (Table 1), no other patterns were strong. When $\%$ silt and \% sand were combined into a single metric, Año Nuevo has higher \% sand: \% silt and soil water content [Supplementary Figure S1, \% sand: \%silt $\left(F_{2,15}=39.04\right.$, $p<0.0001)]$.

\section{Bacterial Endophytes Overall Community Description}

A total of 83 distinct bacterial OTUs were recovered from the 15 needle and three bud samples. These sequence data have been submitted to the GenBank databases under BioProject accession number PRJNA303051. Rarefaction plots saturated, indicating that we did not under-sample the bacterial communities at the 97\% OTU level (Supplementary Figure S3). Overall our samples consisted of 20 bacterial families. There were three families (Bdellovibrionaceae, Methylobacteriaceae, and Salinisphaeraceae) unique to buds (not found in the needles).

Our samples were dominated by Proteobacteria (94\% of total sequences), the majority of which belonged to the class Gammaproteobacteria ( $88 \%$ of total sequences). No other phylum was present above $1 \%$. Within the Proteobacteria, other classes were present in low relative abundance (e.g., Alphaproteobacteria 1.6\%, and Betaproteobacteria 3.9\% of total sequences). The dominance of Gammaproteobacteria reflects the dominance of a few specific OTUs in most of our samples (Figure 1A). The most common OTU in our dataset, Enterobacteriaceae9, belonged to the Enterobacteriaceae, and made up on average 70,12 , and $53 \%$ of the sequences from Cambria, Monterey, and Año Nuevo samples, respectively. This OTU shares $100 \%$ identity to sequences from Rahnella, Serratia, and Ewingella isolates and clones from various plant tissues. The second most common OTU (Erwinia) was present at a higher relative abundance in the Monterey samples (42\%) than the samples from Cambria (11\%) and Ano Nuevo (11\%). Two other OTUs (Enterobacteriaceae7 and Enterobacteriaceae2) belonging to the Enterobacteriaceae were also present at high relative abundance in many samples (Figure 1A).

\section{Community Structure as a Function of Population}

Alpha diversity (the diversity of needle microbiota within a single tree) was estimated by Chaol and Shannon indices (Supplementary Figures S4A-C). No difference in alpha diversity was found among locations for either the Chaol index $\left(F_{2,12}=2.129, p=0.1617\right)$ or the Shannon index $\left(F_{2,12}=2.836\right.$, $p=0.098)$.

Bacterial community abundances were sorted into an ordination plot according to community similarity (Figure 2A). There was significant clustering based on population $\left(R^{2}=0.35\right.$, $p=0.006)$. Four OTUs were significantly associated with Monterey while a single OTU was significantly associated with both Cambria and Año Nuevo. Sphingomonas2 (stat $=0.719$, $p=0.006$ ), Erwinia (stat $=0.680, p=0.003$ ), Methylocystaceae 2 (stat $=0.513, p=0.023$ ), and Salinisphaeraceae (stat $=0.383$, $p=0.038)$ are strongly and significantly associated with Monterey while Enterobacteriaceae9 (stat $=0.716, p=0.006$ ) is strongly and significantly associated with Cambria and Año Nuevo (Figure 2A).

\section{Community Structure as a Function of Environmental Characteristics}

Environmental characteristics were important variables for shaping bacterial alpha diversity; however, specific results differed by indices (Supplementary Figure S5). When alpha diversity was assessed using the Chaol index, neither soil water content $\left(F_{1,10}=1.841, p=0.2046\right)$, nor any of the measures of soil texture (\% silt: $F_{1,10}=0.2584, p=0.6222, \%$ clay: $F_{1,10}=2.827, p=0.1236$, and \% sand: $F_{1,10}=0.5294$, $p=0.4835$ ) significantly altered alpha diversity (Supplementary Figures $\mathrm{S} 6 \mathrm{~B}, \mathrm{E}, \mathrm{H}, \mathrm{K})$. When alpha diversity was assessed using the Shannon index, $\%$ silt significantly decreased alpha diversity $\left(F_{1,10}=6.533, p=0.0286\right)$, but soil water content $\left(F_{1,10}=0.4496, p=0.5177\right), \%$ sand $\left(F_{1,10}=1.794, p=0.2101\right)$, and $\%$ clay $\left(F_{1,10}=1.466, p=0.2538\right)$ did not significantly alter alpha diversity (Supplementary Figures S5C,F,I,L). When \% silt and $\%$ sand were combined into a single metric, results echoed these patterns (Supplementary Figure S6). When \% sand and \% silt were combined into a single metric, the ratio significantly increased alpha diversity as assessed by the Shannon diversity index, in line with the fact that \% silt alone decreased the Shannon index.

While soil water content $\left(R^{2}=0.14, p=0.096\right), \%$ sand $\left(R^{2}=0.07, p=0.310\right)$, and \% clay $\left(R^{2}=0.03, p=0.694\right)$ were not significant structuring factors of bacterial assemblages, $\%$ silt was important for structuring bacterial assemblages $\left(R^{2}=0.17, p=0.049\right.$, Figure 3A). When $\%$ silt and $\%$ sand were combined into a single metric, none of the environmental characteristics were significant structuring factors of bacterial 
A

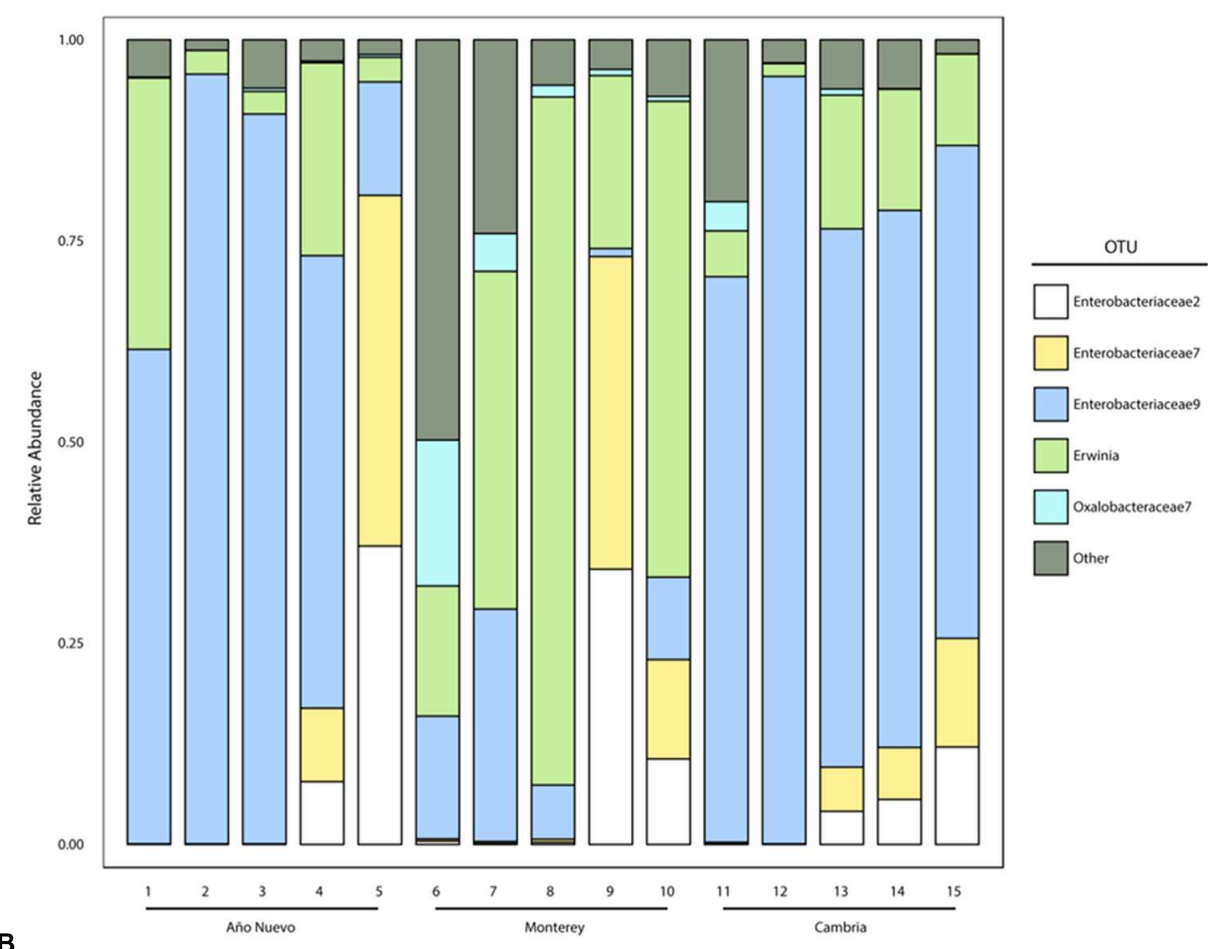

B

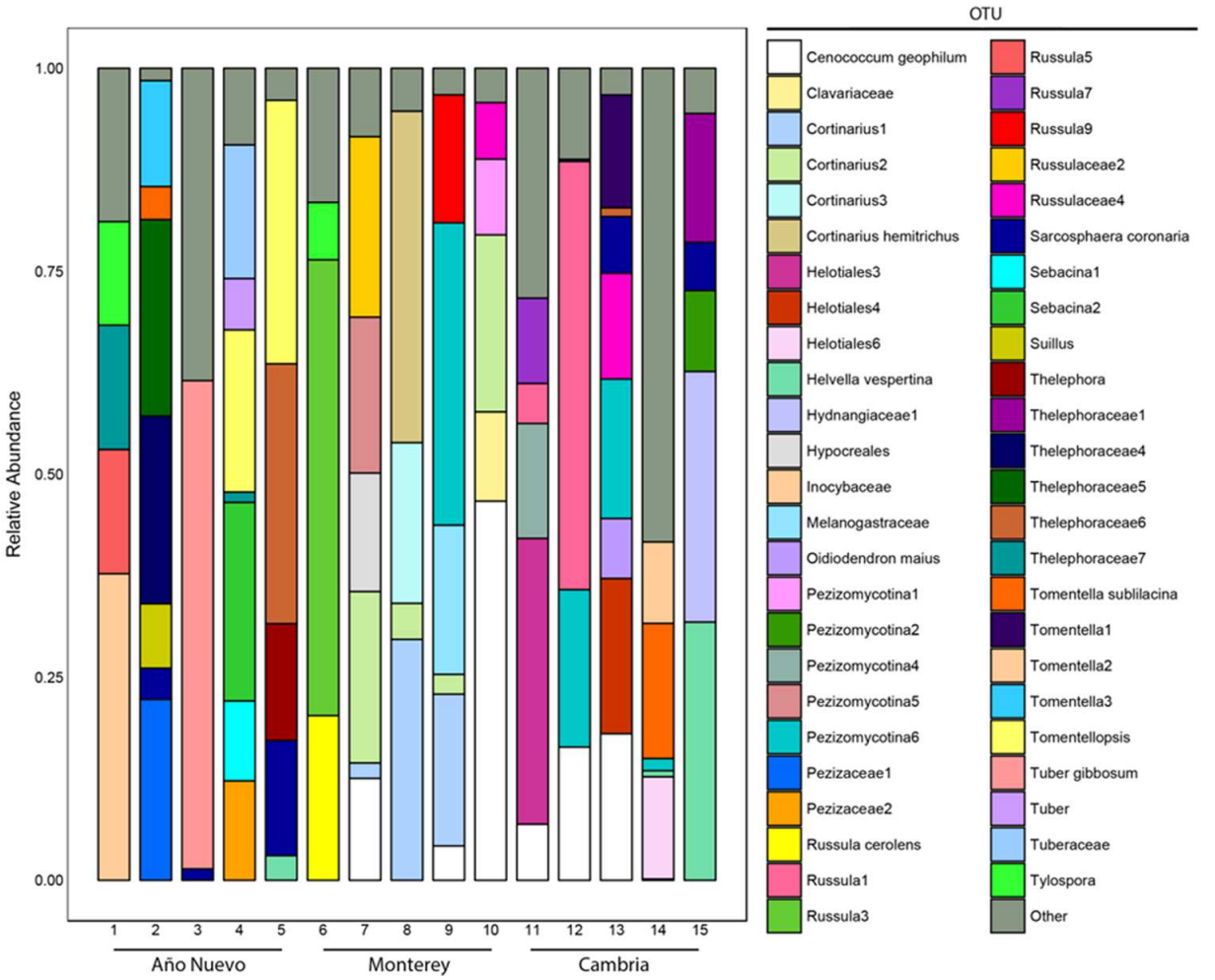

FIGURE 1 | Relative abundances of various major bacterial (A) and fungal (B) taxa recovered from Año Nuevo, Monterey, and Cambria, CA, USA. Relative abundance of families was calculated as the proportion of sequences belonging to a particular lineage of all 16S rRNA (bacteria) and ITS (fungi) gene sequences recovered from each site. Sequences were pooled at the level of the tree. Only those OTUs which represent $>90 \%$ of the total tips are identified separately via color while the remaining OTUs were grouped into an 'Other' category for visualization. 


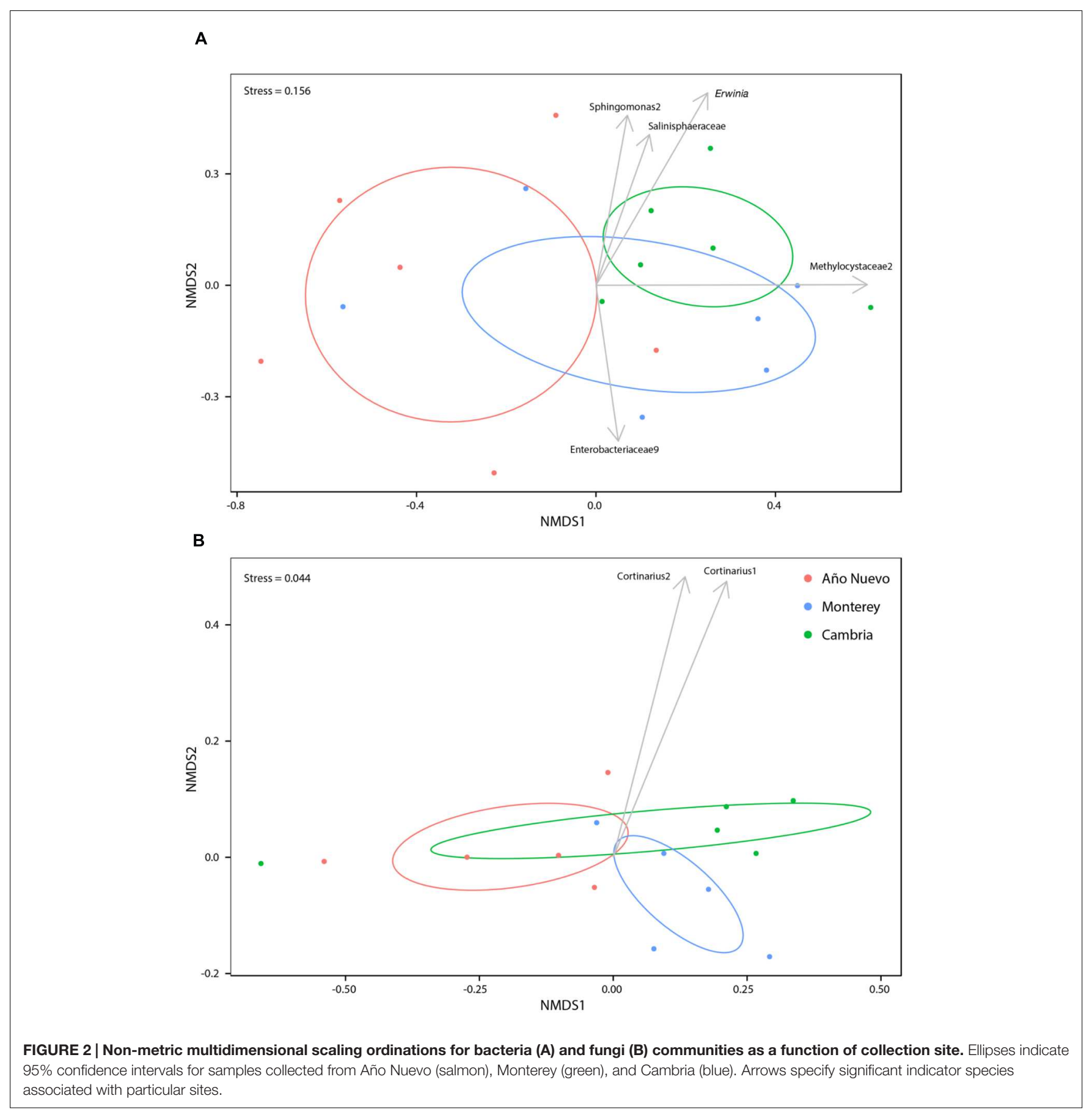

assemblages [Supplementary Figure S7; soil water content $\left(R^{2}=0.14, p=0.08\right), \%$ sand: $\%$ silt $\left(R^{2}=0.15, p=0.062\right)$, and $\%$ clay $\left.\left(R^{2}=0.13, p=0.087\right)\right]$. No bacterial OTUs were correlated $(>0.5)$ with soil water content (Supplementary Figure S8). There were no strong correlations between bacterial OTUs and soil texture but some OTUs tended to prefer specific soil characteristics. While no OTUs were negatively correlated with \% clay, Acetobacteraceae6 (0.6131) tended to be positively correlated with \% clay (Supplementary Figure S8). Sphingomonas2 (0.7343) and Methylocystaceae2 (0.6021) tended to be positively correlated with \% silt and Enterobacteriaceae9 $(-0.6962)$ tended to be negatively correlated with \% silt. No OTUs were correlated with \% sand (Supplementary Figure S8).

When $\%$ silt and \% sand were combined into a single metric, correlations of OTUs with environmental characteristics changed marginally. One bacterial OTU was moderately positively correlated $(>0.5)$ with soil water content (Burkholderiales2: 0.5338, Supplementary Figure S10). Echoing results when environmental variables were analyzed separately, there were no strong correlations between bacterial OTUs and soil texture 
A

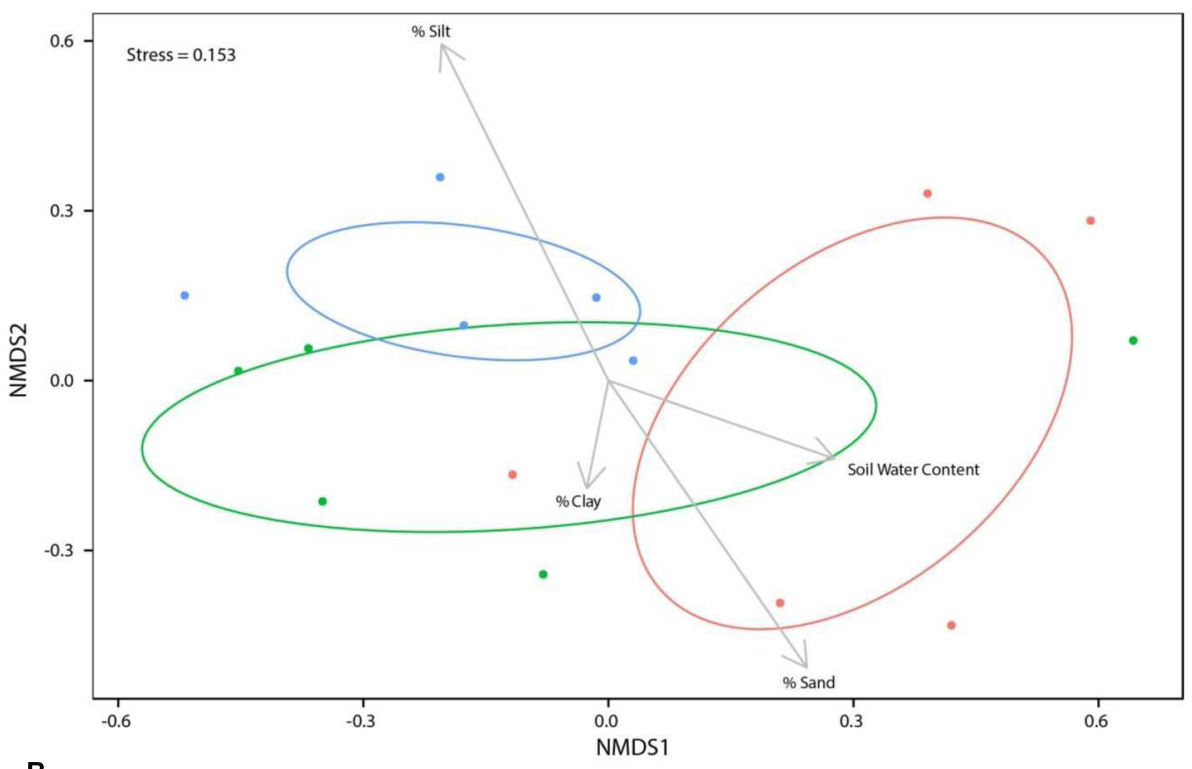

B

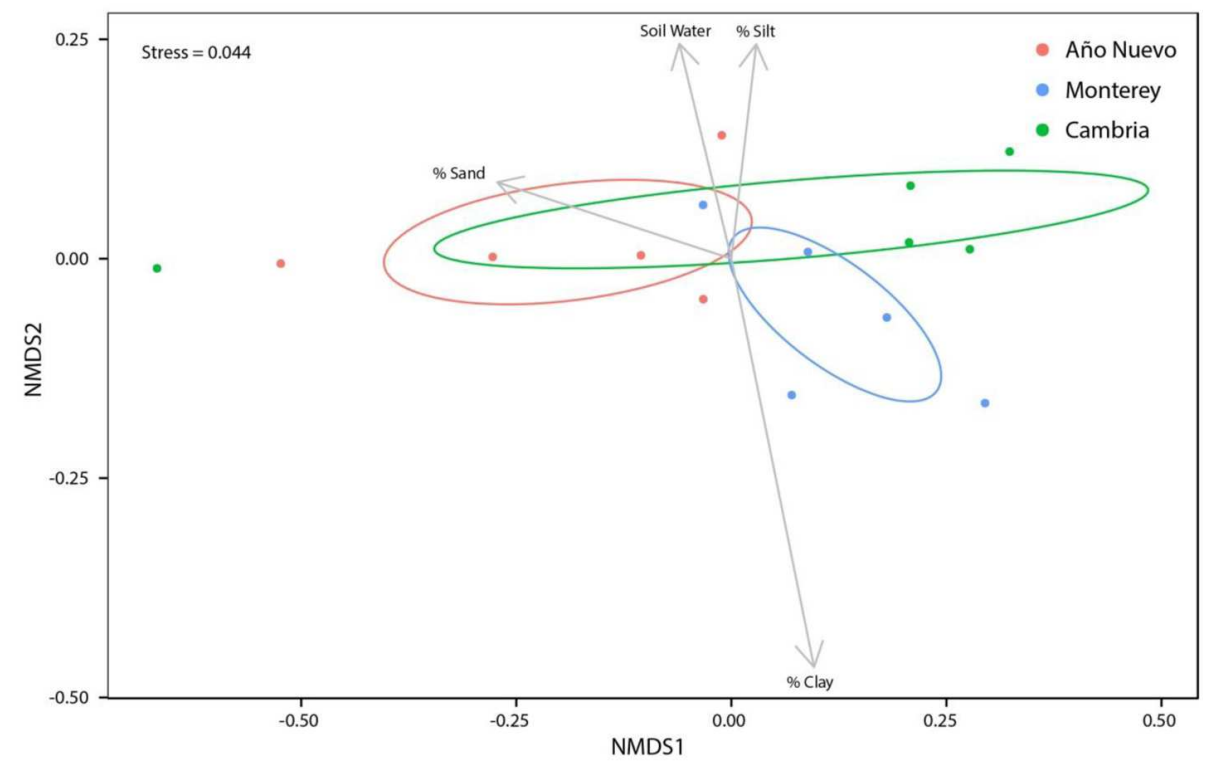

FIGURE 3 | Non-metric multidimensional scaling ordinations for bacteria (A) and fungi (B) communities as a function of environmental variables. Ellipses indicate 95\% confidence intervals for samples collected from Año Nuevo (salmon), Monterey (green), and Cambria (blue). Arrows specify association of environmental variables with particular sites.

but some OTUs tended to prefer specific soil characteristics. Sphingomonas2 $(-0.5474)$ was negatively correlated with \% clay, and Cystobacterineae2 (0.5261), Enterobacteriaceae9 (0.5527), and Acetobacteraceae6 (0.6131) tended to be positively correlated with \% clay (Supplementary Figure S9). Sphingomonas2 $(-0.5152)$ tended to be negatively correlated with \% sand: \% silt and Janthinobacterium (0.5107), Acetobacteraceae16 (0.547), and Enterobacteriaceae9 (0.5918) tended to be positively correlated with \% sand: \% silt (Supplementary Figure S9).

\section{Community Structure as a Function of Tissue Type}

Alpha diversity differed between tissue type (bud vs. needle) when assessed using the Chaol index $\left(F_{1,4}=13.09, p=0.0224\right)$ but not when assessed using the Shannon index $\left(F_{1,4}=0.5922\right.$, $p=0.4845$, Supplementary Figure S10).

Tissue type was a weak structuring factor of bacterial assemblages $\left(R^{2}=0.44, p=0.10\right)$ and communities tended to group accordingly, although there was a fair amount of scatter in NMDS ordinations (Supplementary Figure S11). 
No bacterial species were significantly associated with either tissue type despite Bdellovibrionaceae, Methylobacteriaceae, and Salinisphaeraceae being restricted to buds only.

\section{ECM Fungal Species \\ Overall Community Description}

The ECM fungal community was identified from a total of 6792 colonized root tips (Año Nuevo: 1976, Monterey: 2478, Cambria: 2338), and consisted of 88 OTUs from 32 families (Figure 1B). The fungal sequence data for this project have been submitted to the GenBank databases under the accession numbers KU509057 - KU509213. The three most common families were Cortinariaceae (23\% of total tips), Thelephoraceae ( $22 \%$ of total tips), and Russulaceae (16\% of total tips).

\section{Community Structure as a Function of Population}

No difference in alpha diversity was found among locations for either the Chaol index $\left(F_{2,12}=0.1368, p=0.8734\right)$ or the Shannon index $\left(F_{2,12}=0.1332, p=0.8766\right.$, Supplementary Figure S4D-F).

Mycorrhizal community abundances were sorted into an ordination plot according to community similarity (Figure 2B). Population was a significant structuring factor of mycorrhizal assemblages $\left(R^{2}=0.19, p=0.007\right)$, and communities tended to group accordingly (Figure $2 \mathbf{B}$ ). Cortinarius2 was strongly and significantly associated with Monterey $(p=0.012)$, while no OTUs were significantly associated with either Cambria or Año Nuevo.

\section{Community Structure as a Function of Environmental Characteristics}

No difference in alpha diversity was found among environmental characteristics for either the Chaol index (soil water content: $F_{1,10}=0.0036, p=0.9532 ; \%$ silt: $F_{1,10}=0.0977, p=0.7610$; $\%$ sand: $F_{1,10}=2.102, p=0.1778$; $\%$ clay: $F_{1,10}=0.0998$, $p=0.7586$ ) or the Shannon index (soil water content: $F_{1,10}=0.2526, p=0.6261 ; \%$ silt: $F_{1,10}=0.0981, p=0.7606$; $\%$ sand: $F_{1,10}=0.7501, p=0.4068$; $\%$ clay: $F_{1,10}=0.0258$, $p=0.8756$, Supplementary Figure S12). When $\%$ silt and $\%$ sand were combined into a single metric, results echoed these patterns (Supplementary Figure S13).

Soil water content was a significant structuring factor of mycorrhizal assemblages $\left(R^{2}=0.09, p=0.039\right)$ but none of the measures of soil texture (\% silt: $R^{2}=0.06, p=0.843, \%$ sand: $R^{2}=0.08, p=0.295$, \% clay: $R^{2}=0.07, p=0.550$ ) were significant structuring factors (Figure $3 \mathbf{B}$ ). When $\%$ silt and $\%$ sand were combined into a single metric, results echoed these patterns (Supplementary Figure S14). Correlation analysis indicated that three fungal OTUs were highly correlated with soil water content [Tuber gibbosum (0.7335), Paratritirachium (0.7335), Russula8 (0.7335)] but no OTUs were negatively correlated with soil water content (Supplementary Figure S10). No fungal OTUs were significantly correlated with \% clay or \% sand, but Cortinarius2 (0.6053) was positively correlated with $\%$ silt (Supplementary Figure S15). When \% silt and \% sand were combined into a single metric, correlations of OTUs with soil water content did not change (Supplementary Figure S16), but correlations with environmental characteristics changed marginally such that Russula4 (0.5439), Russula5 (0.5439), Russula6 (0.5439) and Inocybaceae (0.5439) were positively correlated with \% sand: \% silt (Supplementary Figure S16). Echoing results in which environmental variables are analyzed separately, no fungal OTUs were significantly correlated with \% clay (Supplementary Figure S16).

\section{Distribution of Fungal Traits Involved with Foraging Strategy}

The distribution of fungal traits associated with foraging strategy was dependent upon population for exploration type $\left(\chi^{2}=254.2, p<0.0001\right)$, rhizomorph production $\left(\chi^{2}=30.88, p<0.0001\right)$, and hydrophobicity $\left(\chi^{2}=30.88\right.$, $p<0.0001)$. Specifically, ECM fungi with the medium distance exploration type were most prominent at Monterey and Cambria but ECM fungi with the short distance exploration type were more prominent at Año Nuevo (Supplementary Figure S17). Additionally, ECM fungi at Monterey were more likely to produce rhizomorphs and be hydrophobic while the reverse was true at Año Nuevo where ECM were less likely to produce rhizomorphs and be hydrophilic. There was no difference in either fungal trait for fungi at Cambria.

Exploration type of the ECM fungi significantly interacted with several of the environmental factors to influence fungal frequency (Soil Water Content: $p<0.0001$, \% sand: $p<0.0001$, $\%$ silt: $p<0.0001, \%$ clay: $p<0.0001)$. Rhizomorph production significantly interacted with several of the environmental factors to influence fungal frequency (Soil Water Content: $p=0.0 .0054$, $\%$ sand: $p<0.0001$, $\%$ silt: $p<0.0001$, $\%$ clay: $p=0.1241)$. Hydrophobicity significantly interacted with several of the environmental factors to influence fungal frequency (Soil Water Content: $p=0.0054, \%$ sand: $p<0.0001, \%$ silt $p<0.0001, \%$ clay: $p=0.1241)$.

\section{Interaction of Bacterial Endophytes and ECM Fungi}

CAP analysis with Type I ANOVA indicates that Cortinarius1 $\left(F_{1,8}=4.678, p=0.013\right)$ was an important structuring factor for bacterial assemblages and Sarcosphaera coronaria $\left(F_{1,8}=2.399, p=0.074\right)$ tended to be important as well (Figure 4A). This relationship changed slightly when the model was conditioned for population before constraining for other variables (Cortinarius1: $F_{1,8}=2.9, p=0.069$, Sarcosphaera coronaria: $F_{1,8}=3.314, p=0.048$, Pezizomycotina 6: $F_{1,8}=2.973, p=0.087$, Figure 4B) and when the model was conditioned for the environmental characteristics before constraining for other variables (Cortinarius1: $F_{1,8}=2.889$, $p=0.075$, Sarcosphaera coronaria: $F_{1,8}=2.8, p=0.058$, Figure 4C).

We also investigated the role foraging traits play in structuring bacterial endophyte communities. None of the possible exploration types significantly structured bacterial assemblages (Table 2); however, the long distance exploration type tended to be associated with the bacterial species Enterobacteriaceae9 
A
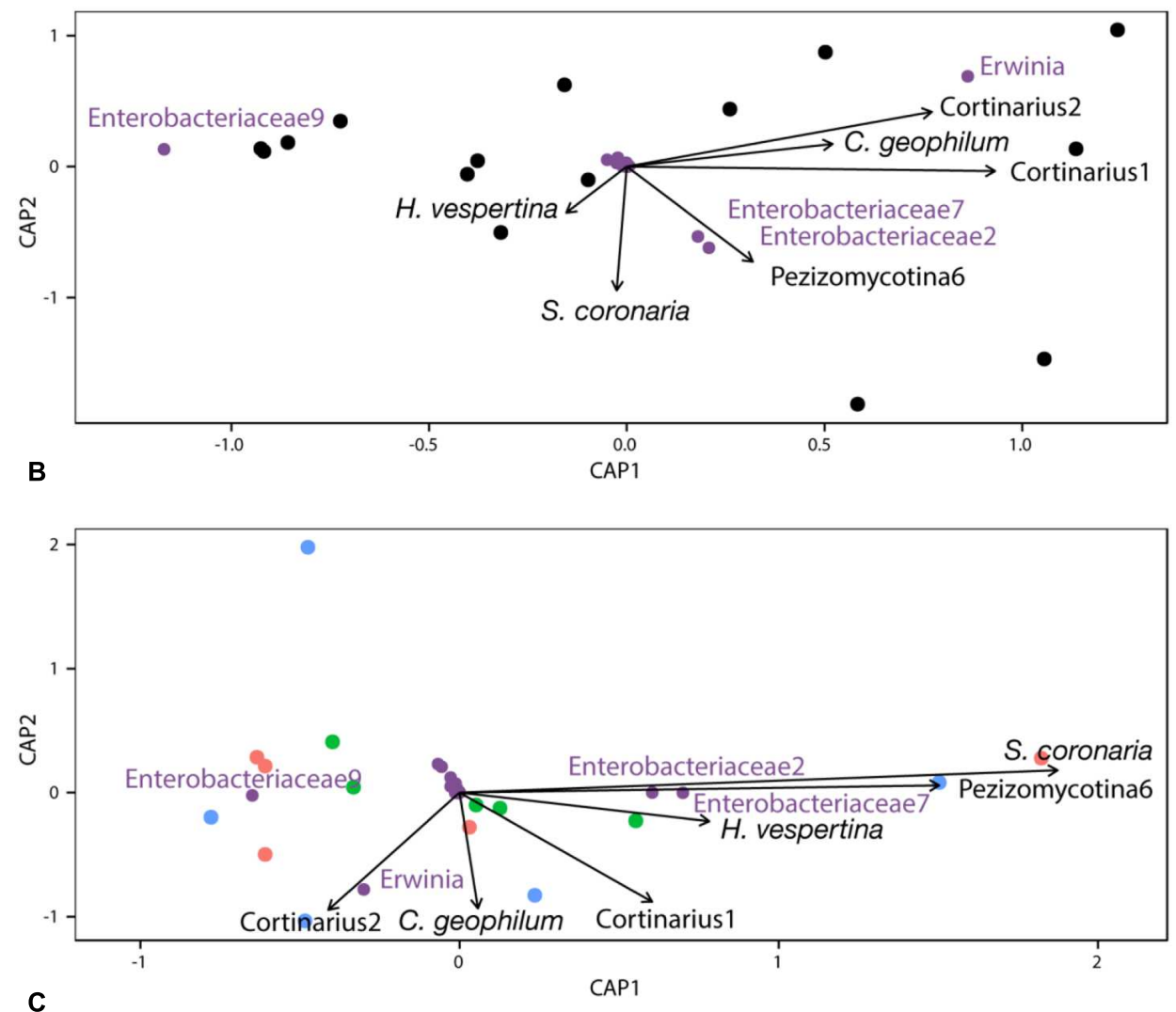

C

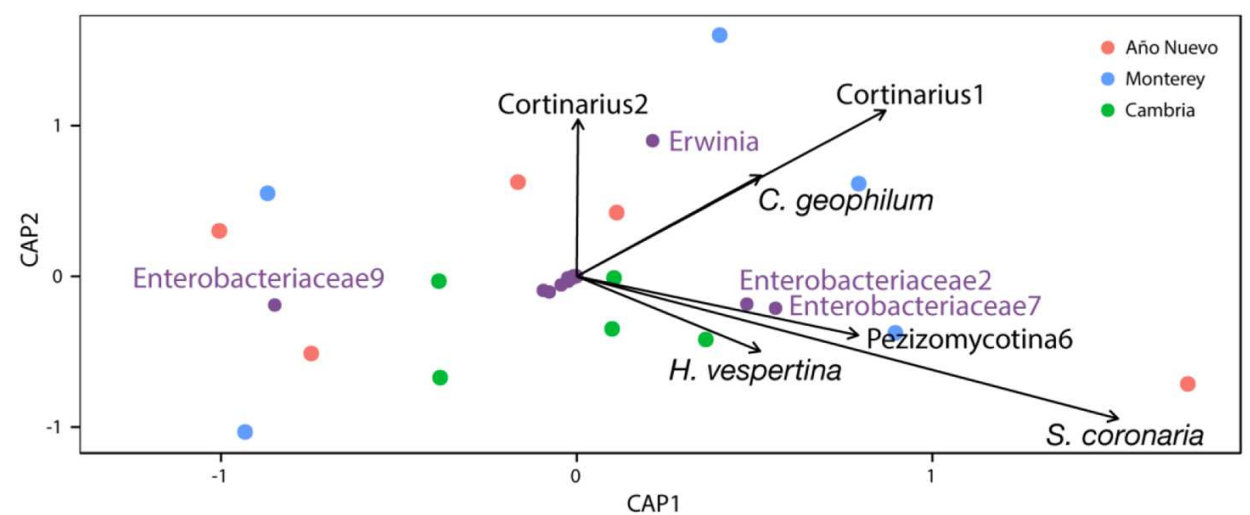

FIGURE 4 | Constrained analysis of principal coordinates with no conditions (A), conditioned by population (B), and conditioned by environment (C).

and the medium distance type tended to be associated with Erwinia (Supplementary Figure S18). Neither rhizomorph production nor hydrophobicity significantly structured bacterial assemblages (Table 2). Conditioning the model with population or the environmental characteristics before constraining for other variables changed these results such that the long distance exploration type tended to be important for structuring the bacterial assemblages $\left(F_{1,6}=2.294, p=0.092\right.$, Table 2).

\section{DISCUSSION}

The plant microbiome is highly diverse, yet little is understood regarding the interaction of microbes from multiple guilds. Our results suggest the potential for relationships between specific ECM fungi and bacterial endophyte communities that are likely to be influenced by population and environmental characteristics. Specifically, we found that the fungal OTU Cortinarius1 was significant in structuring the bacterial endophyte community, 
TABLE 2 | ANOVA tables from CAP models describing the relationship between fungal traits describing foraging strategy and bacterial assemblages.

\begin{tabular}{|c|c|c|c|c|c|c|c|c|c|c|c|c|}
\hline & \multicolumn{4}{|c|}{ Default } & \multicolumn{4}{|c|}{ Population } & \multicolumn{4}{|c|}{ Environmental Characteristics } \\
\hline & Df & ss & $\boldsymbol{F}$ & $\operatorname{Pr}(>F)$ & Df & ss & $\boldsymbol{F}$ & $\operatorname{Pr}(>F)$ & Df & SS & $\boldsymbol{F}$ & $\operatorname{Pr}(>F)$ \\
\hline \multicolumn{13}{|l|}{ Exploration type } \\
\hline Contact & 1 & 0.0989 & 0.4655 & 0.782 & 1 & 0.1435 & 0.9495 & 0.425 & 1 & 0.2191 & 1.551 & 0.217 \\
\hline Long distance & 1 & 0.1516 & 0.7137 & 0.559 & 1 & 0.1303 & 0.8620 & 0.435 & 1 & 0.3241 & 2.294 & 0.092 \\
\hline Medium distance & 1 & 0.1352 & 0.6363 & 0.602 & 1 & 0.0372 & 0.2460 & 0.937 & 1 & 0.0362 & 0.2561 & 0.889 \\
\hline Short distance & 1 & 0.0767 & 0.3612 & 0.843 & 1 & 0.0722 & 0.4780 & 0.751 & 1 & 0.1300 & 0.9201 & 0.448 \\
\hline Residual & 10 & 2.1247 & & & 8 & 1.2090 & & & 6 & 0.8476 & & \\
\hline \multicolumn{13}{|c|}{ Rhizomorph production } \\
\hline No Rhizomorphs & 1 & 0.0353 & 0.1838 & 0.966 & 1 & 0.0373 & 0.2601 & 0.931 & 1 & 0.0522 & 0.3241 & 0.856 \\
\hline Rhizo-forming & 1 & 0.2456 & 1.278 & 0.255 & 1 & 0.1206 & 0.8407 & 0.488 & 1 & 0.2153 & 1.336 & 0.266 \\
\hline Residual & 12 & 2.3063 & & & 10 & 1.4343 & & & 8 & 1.2894 & & \\
\hline \multicolumn{13}{|l|}{ Hydrophobicity } \\
\hline Hydrophilic & 1 & 0.0353 & 0.1838 & 0.969 & 1 & 0.0373 & 0.2601 & 0.923 & 1 & 0.0522 & 0.3241 & 0.876 \\
\hline Hydrophobic & 1 & 0.2456 & 1.2779 & 0.303 & 1 & 0.1206 & 0.8407 & 0.478 & 1 & 0.2153 & 1.336 & 0.268 \\
\hline Residual & 12 & 2.3063 & & & 10 & 1.4343 & & & 8 & 1.2894 & & \\
\hline
\end{tabular}

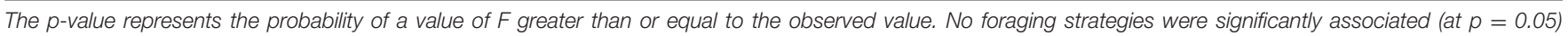

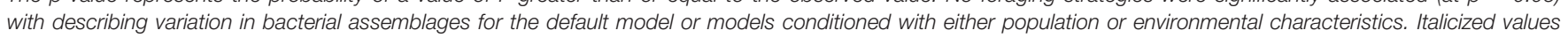
represent significance between $p=0.05$ and $p=0.1$. Df, degrees of freedom; SS, sums of squares; F, F-statistic.

and that the OTU Sarcosphaera coronaria was marginally significant, but that when either population or environmental characteristics were taken into account, the importance of particular ECM fungi for structuring bacterial communities changed such that Cortinarius1 became a less important factor and $S$. coronaria became a more important factor. These results justify further research into the relationship between fungal and bacterial components of the plant microbiome.

The ecological and evolutionary implications of these results are important as the processes and patterns which structure microbial communities remains an area of developing research. The advancement of molecular methodology has extended our knowledge of the factors that influence aspects of microbial communities including diversity, niche partitioning, competition, spatial variability, and functional traits (Peay et al., 2008; Poole et al., 2012), but the role microbial species interactions play in altering these factors is an area of developing research. For example, ecological theory indicates that species interactions may either enlarge the realized niches of species (facilitation; Bruno et al., 2003) or contract the realized niche (competition; Pianka, 1981) but these concepts have yet to be extended to include the interactions of microbes from multiple guilds (e.g., fungi and bacteria). Furthermore, the role of environmental variables in influencing multispecies interactions is generally neglected. Our research indicates that, in addition to abiotic variables, consideration of biotic interactions, such as those between bacterial endophytes and ECM fungi, may be important for understanding the factors that structure microbial communities.

\section{Foraging Traits of ECM Fungi as Structuring Forces}

Fungal life-history traits such as those associated with foraging strategy are likely to provide important insight into how species interactions may ultimately shape microbial communities. Across populations and environmental factors, none of the traits associated with fungal foraging strategy types were significantly associated with bacterial assemblages as a whole but two bacterial species were more likely to be associated with specific ECM fungal traits associated with foraging strategy. Members of the bacterial genus Erwinia were correlated to the abundance of ECM from the medium exploration type while members of the family Enterobacteriaceae9 were correlated to long distance exploration types. ECM fungi belonging to the long distance exploration type make a higher investment in transport mycelium, indicating a higher carbon cost to their host than taxa that form less carbon intensive rhizomorphs such as those from the short, contact and some medium distance exploration types. Therefore, conditions that favor greater belowground carbon allocation are likely to favor long distance exploration types while conditions which favor low belowground carbon allocation are likely to favor other exploration types. The dominant bacteria in this study - Enterobacteriaceae and Erwinia - could in theory be mutualists, commensal, or opportunistic pathogens of Monterey pine. The presence of bacteria that alleviate plant stress or promote plant growth could allow for conditions that favor greater belowground carbon allocation, leading to an increased presence of long distance exploration fungal types. On the other hand, these bacteria could be opportunists which take advantage of the elevated drought stress Monterey pine populations are currently experiencing (Hoeksema and Rúa, unpublished data). While using a trait-based approach to ECM fungal ecology allows us to link ECM diversity to important ecosystem processes such as nitrogen and carbon cycling (Krause et al., 2014; Aguilar-Trigueros et al., 2015), in order to fully understand the ecological and evolutionary implications of such interactions, further work utilizing eco-physiological studies to examine the potential mechanisms behind these interactions is needed. 
Interestingly, it is only after accounting for variation due to environmental factors that the long distance exploration type tends to be associated with bacterial communities. This is likely because each of the environmental characteristics we measured interacted with the foraging traits to significantly alter the frequency of ECM fungi. Previous studies have found that environmental characteristics can shape the presence and proportion of different ECM exploration types (Suz et al., 2014). In our system, the abundance of the contact exploration type was highest at Monterey and Cambria, suggesting conditions at those sites favoring fungi able to access nutrients from labile nutrient pools, while Año Nuevo was dominated by fungi classified as the long exploration type, suggesting conditions at those sites favoring fungi able to access nutrients from recalcitrant nutrient pools (Supplementary Figure S17) (Lilleskov et al., 2002; Hobbie and Agerer, 2010). Interestingly, the environmental characteristics we measured were more closely related for Año Nuevo and Cambria than Monterey and Cambria (Supplementary Figures S1-S3), suggesting nutrient availability may not track with our environmental characteristics. These results suggest it is not only species interactions but also abiotic factors that may be important for understanding microbial community dynamics in forest ecosystems.

\section{Bacterial Endophyte Community Composition}

While the needle endophyte communities of other conifers surveyed to date have been found to consist largely of bacteria in the lineages Alphaproteobacteria, Acidobacteria, and Firmicutes (Carrell and Frank, 2014, 2015), the endophyte communities of Monterey pine needles in this study consisted largely of Gammaproteobacteria. Across all plant species studied, this class of bacteria is the one most commonly found in endophyte communities (Hardoim et al., 2015). The majority of samples across all three populations were dominated by one or several of four OTUs in the Enterobacteriaceae, a family that is commonly associated with plants, both as mutualists and pathogens. Due to horizontal gene transfer, bacterial groups encompass large diversity in genome content, making it impossible to infer physiology from taxonomic identity at the family or even species level. Mutualistic species in this family, including Klebsiella, Enterobacter, and Rahnella spp., have been found to promote growth, solubilize phosphate, fix nitrogen, and protect plants against fungal pathogens and drought (Chernin et al., 1995; Fouts et al., 2008; Hardoim et al., 2013; Naveed et al., 2014; Upreti and Thomas, 2015). Pathogenic Enterobacteriaceae include Erwinia amylovora, the causative agent of fire blight on apple trees, Erwinia pyrifoliae, which causes bacterial shoot blight in pear, and Erwinia carotovora, the causative agent of soft rot and blackleg potato diseases (Rhim et al., 1999; Shrestha et al., 2003; Bell et al., 2004); however, Erwinia spp. have also been found as endophytes in apparently healthy plants, including in high relative abundance in healthy maples growing in an urban environment (Shen and Fulthorpe, 2015). At this stage, we cannot determine whether the dominant Enterobacteriacae in the Monterey pine foliar endophyte community interacts with the hosts as mutualists, commensals or opportunistic pathogens. The dominance of these taxa as bacterial endophytes could be the result of beneficial interactions, for example through buffering of abiotic stresses imposed on the plant by their harsh coastal environments. Alternatively, they could represent opportunistic bacteria taking advantage of drought-stressed trees. The extent to which selection, dispersal, and drift shape these communities is largely unknown, but it is possible that ecological drift events could influence above-ground endophyte communities over relatively short time scales. For example, immigrated dustassociated bacteria can drastically alter the communities of bacterial communities in the phyllosphere (Rastogi et al., 2012), and significant variation in foliar endophyte communities across seasons has been observed (Shen and Fulthorpe, 2015).

With only 83 OTUs identified, the foliar endophyte community of Monterey pine was less diverse than that of other conifers surveyed with next-generation $16 \mathrm{~S}$ rRNA sequencing (Carrell and Frank, 2014, 2015), but rarefaction analysis indicated that we did not under-sample the community (Supplementary Figure S3). Interestingly, the Gammaproteobacteria from Monterey pine were more readily cultured than bacteria from high elevation pines (Wilson and Frank, unpublished), potentially consistent with opportunistic invasion of Gammaproteobacteria. Further insight into the structure and role of Monterey pine foliar endophyte communities could be resolved with surveys across multiple time points as well as controlled inoculation experiments.

The buds of $P$. sylvestris have been found to consistently host growth-promoting, intracellular bacteria with a potential role in bud elongation and differentiation (Pirttilä et al., 2000, 2004, 2005; Pohjanen et al., 2014). Although bud and needle communities of $P$. radiata in this study were not significantly different as a whole, we identified three bacterial families unique to buds: Bdellovibrionaceae, Methylobacteriaceae, and Salinisphaeraceae. Members of the Bdellovibrionaceae are unique among bacteria in that they often parasitize other Gram-negative bacteria, and have been identified previously as endophytes in hybrid maize (Liu et al., 2012) while members of the Salinisphaeraceae family exhibit extremely high levels of salt tolerance (Vetriani et al., 2014). To our knowledge, members of the Salinisphaeraceae have not previously been identified as endophytes. Given that all members of this family have been isolated from marine and high-salinity environments (Vetriani et al., 2014), the presence of this taxon in Monterey pine buds likely reflects the coastal habitat. Finally, identification of members of the Methylobacteriaceae complements previous research investigating bacterial endophytes in buds, which found that M. extorquens DSM 1360 is a dominant species in P. sylvestris buds throughout the year (Pirttilä et al., 2000, 2005).

Environmental factors were important for shaping bacterial endophyte communities not only by mediating their interaction with ECM fungi but also by directly altering their distribution, emphasizing the important role environmental filtering plays in shaping these communities. Specifically, \% clay and soil water content both decreased bacterial alpha diversity, stressing the potential importance of water availability for shaping these communities. Representative species of the family 
Enterobacteriace, including Klebsiella, Enterobacter, and Citrobacter, have all been isolated from plant species grown in arid environments with similar environmental characteristics (Hayat et al., 2010; Marasco et al., 2012), indicating the potential for endophytes from this class to be advantageous under adverse environmental conditions. Interestingly, in our study system, \% silt and \% sand were found to be correlated (Table 1) but when combined into a single metric, results were not qualitatively different then when left apart (see Supplementary Material). The main effect of combining $\%$ silt and \% sand into a single metric was to marginally alter the magnitude of correlations of bacterial and fungal OTUs with respect to soil texture (Supplementary Figures S9 and S16).

\section{ECM Fungal Community}

Contrary to previous work examining ECM communities in $P$. radiata (Hoeksema et al., 2012), we did not find significant differences in species richness among the populations (Supplementary Figure S4D-F) but population was important for understanding differences in community structure. The ECM fungal community in Monterey was different from those found at Año Nuevo or Cambria (Supplementary Figure S4D-F), which is likely due to differences in the sites' environmental characteristics. Monterey had the lowest soil water content among the three sites and differed greatly from the other sites in all three soil texture measurements (lowest \% clay, lowest $\%$ sand, and highest $\%$ silt, Supplementary Figure S1). Interestingly, the OTU Cortinarius2 was both a significant indicator of the Monterey population and highly positively correlated with the $\%$ silt in the soil but not significantly related to $\%$ sand as might be expected since these environmental variables are correlated in this system (Table 1); however, previous work with the Cortinarius genus indicates members of this genus play an important role in the decomposition of complex organic matter (Hobbie et al., 2013; Bödeker et al., 2014), suggesting this functional trait may be important in high silt environments like Monterey.

\section{CONCLUSION}

Understanding the ecological and evolutionary dynamics that shape plant microbial communities is important for both natural and agroecosystems as well as a wide range of fields,

\section{REFERENCES}

Agerer, R. (2001). Exploration types of ectomycorrhizae. Mycorrhiza 11, 107-114. doi: 10.1007/s005720100108

Agerer, R. (2006). Fungal relationships and structural identity of their ectomycorrhizae. Mycol. Progr. 5, 67-107. doi: 10.1007/s11557-0060505- $\mathrm{x}$

Aguilar-Trigueros, C. A., Hempel, S., Powell, J. R., Anderson, I. C., Antonovics, J., Bergmann, J., et al. (2015). Branching out: towards a trait-based understanding of fungal ecology. Fungal Biol. Rev. 29, 34-41. doi: 10.1016/j.fbr.2015.03.001 including biotechnology and sustainable agriculture; however, in order to more fully understand these processes, research which explores the variation in microbial community structure due to interactions among microbes is vital (Dickie et al., 2012; Hanson et al., 2012; Rillig et al., 2015). By uniting two ubiquitous microbial communities, this research represents a first crucial step toward understanding such interactions in forests.

\section{AUTHOR CONTRIBUTIONS}

MR, EW, and AF conceived and designed the experiment. MR and EW collected field samples; MR and SS performed fungal laboratory analyses; EW and AM performed bacterial laboratory analyses; MR analyzed the data with input from AF; $\mathrm{MR}$, and AF contributed reagents/materials/analysis tools; MR wrote the paper. All authors revised the manuscript critically for important intellectual content and approved the final version of the manuscript.

\section{ACKNOWLEDGMENTS}

We thank Dr. J. Steve Brewer for statistical consultation, Luke Walker for help with figures, and members of the Classen Lab at UTK for comments on an earlier version of this manuscript. We also thank Steve Auten at Cal Poly Swanton Pacific Ranch and Donald Canestro at the University of California (Santa Barbara) Kenneth S. Norris Rancho Marino Reserve for help with field collections. This work was supported by UC Merced start-up funds to AF, funds from the Sally McDonnell Barksdale Honors College at the University of Mississippi to SS, a National Science Foundation (NSF) Graduate Research Fellowship to EW, and a NSF Postdoctoral Research Fellowship in Biology under Grant No. DBI-12-02676 to MR. MR was also supported by a postdoctoral fellowship at NIMBioS, sponsored by NSF grant no. DBI-1300426 and the University of Tennessee, Knoxville, TN, USA. JH was supported by NSF award DEB-1119865.

\section{SUPPLEMENTARY MATERIAL}

The Supplementary Material for this article can be found online at: http://journal.frontiersin.org/article/10.3389/fmicb. 2016.00399

Altschul, S. F., Gish, W., Miller, W., Myers, E. W., and Lipman, D. J. (1990). Basic local alignment search tool. J. Mol. Biol. 215, 403-410. doi: 10.1016/S00222836(05)80360-2

Anderson, I. C., and Cairney, J. W. G. (2007). Ectomycorrhizal fungi: exploring the mycelial frontier. FEMS Microbiol. Rev. 31, 388-406. doi: 10.1111/j.15746976.2007.00073.x

Arnold, A. E., Henk, D. A., Eells, R. L., Lutzoni, F., and Vilgalys, R. (2007). Diversity and Phylogenetic affinities of foliar fungal endophytes in loblolly pine inferred by culturing and environmental PCR. Mycologia 99, 185-206. doi: 10.3852/mycologia.99.2.185 
Aronesty, E. (2011). ea-utils : Command-line Tools for Processing Biological Sequencing Data. Available at: http://code.google.com/p/ea-utils

Axelrod, D. I. (1986). Cenozoic history of some western american pines. Ann. Missouri Bot. Garden 73, 565-641. doi: 10.2307/2399194

Bell, K. S., Sebaihia, M., Pritchard, L., Holden, M. T. G., Hyman, L. J., Holeva, M. C., et al. (2004). Genome sequence of the enterobacterial phytopathogen Erwinia carotovora subsp. atroseptica and characterization of virulence factors. Proc. Natl. Acad. Sci. U.S.A. 101, 11105-11110. doi: 10.1073/pnas.0402424101

Bever, J. D. (2003). Soil community feedback and the coexistence of competitors: conceptual frameworks and empirical tests. New Phytol. 157, 465-473. doi: 10.1046/j.1469-8137.2003.00714.x

Bödeker, I. T. M., Clemmensen, K. E., de Boer, W., Martin, F., Olson, Å., and Lindahl, B. D. (2014). Ectomycorrhizal Cortinarius species participate in enzymatic oxidation of humus in northern forest ecosystems. New Phytol. 203, 245-256. doi: 10.1111/nph.12791

Bokulich, N. A., Subramanian, S., Faith, J. J., Gevers, D., Gordon, J. I., Knight, R., et al. (2013). Quality-filtering vastly improves diversity estimates from Illumina amplicon sequencing. Nat. Methods 10, 57-59. doi: 10.1038/nmeth.2276

Bruno, J. F., Stachowicz, J. J., and Bertness, M. D. (2003). Inclusion of facilitation into ecological theory. Trends Ecol. Evol. 18, 119-125. doi: 10.1016/S01695347(02)00045-9

Caporaso, J. G., Bittinger, K., Bushman, F. D., DeSantis, T. Z., Andersen, G. L., and Knight, R. (2010a). PyNAST: a flexible tool for aligning sequences to a template alignment. Bioinformatics 26, 266-267. doi: 10.1093/bioinformatics/btp636

Caporaso, J. G., Kuczynski, J., Stombaugh, J., Bittinger, K., Bushman, F. D., Costello, E. K., et al. (2010b). QIIME allows analysis of highthroughput community sequencing data. Nat. Methods 7, 335-336. doi: 10.1038/nmeth.f.303

Carrell, A. A., and Frank, A. C. (2014). Pinus flexilis and Piceae engelmannii share a simple and consistent needle endophyte microbiota with a potential role in nitrogen fixation. Front. Microbiol. 5:333. doi: 10.3389/fmicb.2014.00333.

Carrell, A. A., and Frank, A. C. (2015). Bacterial endophyte communities in the foliage of coast redwood and giant sequoia. Front. Microbiol. 6:e01008. doi: 10.3389/fmicb.2015.01008

Carroll, G. (1988). Fungal endophytes in stems and leaves: from latent pathogen to mutualistic symbiont. Ecology 69, 2-9. doi: 10.2307/1943154

Chanway, C. P. (1996). Endophytes: they're not just fungi! Can. J. Bot. 74, 321-322. doi: 10.1139/b96-040

Chanway, C. P., Anand, R., and Yang, H. (2014). "Nitrogen fixation outside and inside plant tissues," in Advances in Biology and Ecology of Nitrogen Fixation, ed. T. Ohyama (InTech).

Chelius, M. K., and Triplett, E. W. (2001). The diversity of archaea and bacteria in association with the roots of Zea mays L. Microb. Ecol. 41, 252-263. doi: $10.1007 / \mathrm{s} 002480000087$

Chernin, L., Ismailov, Z., Haran, S., and Chet, I. (1995). Chitinolytic enterobacter agglomerans antagonistic to fungal plant pathogens. Appl. Environ. Microbiol. 61, 1720-1726.

De Cáceres, M., and Legendre, P. (2009). Associations between species and groups of sites: indices and statistical inference. Ecology 90, 3566-3574. doi: 10.1890/081823.1

De Cáceres, M., Legendre, P., and Moretti, M. (2010). Improving indicator species analysis by combining groups of sites. Oikos 119, 1674-1684. doi: 10.1111/j.1600-0706.2010.18334.x

de Mendiburu, F. (2014). Agricolae: Statistical Procedures for Agricultural Research. $\mathrm{R}$ package version 1.2-1. Available at: http://CRAN.R-project.org/package= agricolae

DeSantis, T. Z., Hugenholtz, P., Larsen, N., Rojas, M., Brodie, E. L., Keller, K., et al. (2006). Greengenes, a chimera-checked 16S rRNA gene database and workbench compatible with ARB. Appl. Environ. Microbiol. 72, 5069-5072. doi: 10.1128/aem.03006-3005

Dickie, I. A., Fukami, T., Wilkie, J. P., Allen, R. B., and Buchanan, P. K. (2012). Do assembly history effects attenuate from species to ecosystem properties? A field test with wood-inhabiting fungi. Ecol. Lett. 15, 133-141. doi: 10.1111/j.14610248.2011.01722.x

Edgar, R. C. (2010). Search and clustering orders of magnitude faster than BLAST. Bioinformatics 26, 2460-2461. doi: 10.1093/bioinformatics/btq461
Edgar, R. C. (2013). UPARSE: highly accurate OTU sequences from microbial amplicon reads. Nat. Methods 10, 996-998. doi: 10.1038/ nmeth. 2604

Fogel, R. (1988). Interactions among soil biota in coniferous ecosystems. Agricult. Ecosyst. Environ. 24, 69-85. doi: 10.1016/0167-8809(88)90057-6

Fouts, D. E., Tyler, H. L., DeBoy, R. T., Daugherty, S., Ren, Q., Badger, J. H., et al. (2008). Complete genome sequence of the $\mathrm{N}_{2}$-fixing broad host range endophyte Klebsiella pneumoniae 342 and virulence predictions verified in mice. PLoS Genet. 4:e1000141. doi: 10.1371/journal.pgen. 1000141

Gardes, M., and Bruns, T. D. (1993). ITS primers with enhanced specificity for basidiomycetes-application to the identification of mycorrhizae and rusts. Mol. Ecol. 2, 113-118. doi: 10.1111/j.1365-294X.1993.tb00005.x

Griffin, E., and Carson, W. (2015). The ecology and natural history of foliar bacteria with a focus on tropical forests and agroecosystems. Bot. Rev. 81, 105-149. doi: 10.1007/s12229-015-9151-9159

Grotkopp, E., Rejmánek, M., Sanderson, M. J., and Rost, T. L. (2004). Evolution of genome size in Pines (Pinus) and its life-history correlates: supertree analyses. Evolution 58, 1705-1729. doi: 10.1111/j.0014-3820.2004.tb00456.x

Hanson, C. A., Fuhrman, J. A., Horner-Devine, M. C., and Martiny, J. B. H. (2012). Beyond biogeographic patterns: processes shaping the microbial landscape. Nat. Rev. Microbiol. 10, 497-506. doi: 10.1038/nrmicro2795

Hardoim, P., Nazir, R., Sessitsch, A., Elhottová, D., Korenblum, E., van Overbeek, L., et al. (2013). The new species Enterobacter oryziphilus sp. nov. and Enterobacter oryzendophyticus sp. nov. are key inhabitants of the endosphere of rice. BMC Microbiol. 13:164. doi: 10.1186/1471-2180-13-164

Hardoim, P. R., van Overbeek, L. S., Berg, G., Pirttilä, A. M., Compant, S., Campisano, A., et al. (2015). The hidden world within plants: ecological and evolutionary considerations for defining functioning of microbial endophytes. Microbiol. Mol. Biol. Rev. 79, 293-320. doi: 10.1128/mmbr.00050-14

Hayat, R., Ali, S., Amara, U., Khalid, R., and Ahmed, I. (2010). Soil beneficial bacteria and their role in plant growth promotion: a review. Ann. Microbiol. 60, 579-598. doi: 10.1007/s13213-010-0117-111

Hobbie, E. A., and Agerer, R. (2010). Nitrogen isotopes in ectomycorrhizal sporocarps correspond to belowground exploration types. Plant Soil 327, 71-83. doi: $10.1007 /$ s11104-009-0032-z

Hobbie, E. A., Ouimette, A. P., Schuur, E. A. G., Kierstead, D., Trappe, J. M., Bendiksen, K., et al. (2013). Radiocarbon evidence for the mining of organic nitrogen from soil by mycorrhizal fungi. Biogeochemistry 114, 381-389. doi: 10.1007/s10533-012-9779-z

Hoeksema, J. D., Hernandez, J. V., Rogers, D. L., Mendoza, L. L., and Thompson, J. N. (2012). Geographic divergence in a species-rich symbiosis: interactions between Monterey pines and ectomycorrhizal fungi. Ecology 93, 2274-2285. doi: 10.1890/11-1715.1

Hoeksema, J. D., and Thompson, J. N. (2007). Geographic structure in a widespread plant-mycorrhizal interaction: pines and false truffles. J. Evol. Biol. 20, 1148-1163. doi: 10.1111/j.1420-9101.2006.01287.x

Horton, T. R. (2002). Molecular approaches to ectomycorrhizal diversity studies: variation in ITS at a local scale. Plant Soil 244, 29-39. doi: 10.1023/A:1020268020563

Huang, X., and Madan, A. (1999). Cap3: a DNA sequence assembly program. Genome Res. 9, 868-877. doi: 10.1101/gr.9.9.868

Innerebner, G., Knief, C., and Vorholt, J. A. (2011). Protection of Arabidopsis thaliana against Leaf-Pathogenic Pseudomonas syringae by sphingomonas strains in a controlled model system. Appl. Environ. Microbiol. 77, 3202-3210. doi: 10.1128/aem.00133-111

Izzo, A., Agbowo, J., and Bruns, T. D. (2005). Detection of plot-level changes in ectomycorrhizal communities across years in an old-growth mixedconifer forest. New Phytol. 166, 619-630. doi: 10.1111/j.1469-8137.2005. 01354.x

James, E. K. (2000). Nitrogen fixation in endophytic and associative symbiosis. Field Crops Res. 65, 197-209. doi: 10.1016/S0378-4290(99)00087-8

Ji, P., and Wilson, M. (2002). Assessment of the importance of similarity in carbon source utilization profiles between the biological control agent and the pathogen in biological control of bacterial speck of tomato. Appl. Environ. Microbiol. 68, 4383-4389. doi: 10.1128/aem.68.9.4383-4389.2002 
Jiao, J. Y., Wang, H. X., Zeng, Y., and Shen, Y. M. (2006). Enrichment for microbes living in association with plant tissues. J. Appl. Microbiol. 100, 830-837. doi: 10.1111/j.1365-2672.2006.02830.x

Kõljalg, U., Nilsson, R. H., Abarenkov, K., Tedersoo, L., Taylor, A. F. S., Bahram, M., et al. (2013). Towards a unified paradigm for sequence-based identification of fungi. Mol. Ecol. 22, 5271-5277. doi: 10.1111/mec.12481

Koskimäki, J. J., Pirttilä, A. M., Ihantola, E.-L., Halonen, O., and Frank, A. C. (2015). The intracellular scots pine shoot symbiont methylobacterium extorquens dsm13060 aggregates around the host nucleus and encodes eukaryote-like proteins. mBio 6:e00039. doi: 10.1128/mBio.00039-15.

Krause, S., Le Roux, X., Niklaus, P. A., Van Bodegom, P. M., Lennon, J. T., Bertilsson, S., et al. (2014). Trait-based approaches for understanding microbial biodiversity and ecosystem functioning. Front. Microbiol. 5:251. doi: 10.3389/fmicb.2014.00251

Lepage, B., Currah, R., Stockey, R., and Rothwell, G. (1997). Fossil ectomycorrhizae from the Middle Eocene. Am. J. Bot. 84:410. doi: 10.2307/2446014

Lilleskov, E. A., Hobbie, E. A., and Fahey, T. J. (2002). Ectomycorrhizal fungal taxa differing in response to nitrogen deposition also differ in pure culture organic nitrogen use and natural abundance of nitrogen isotopes. New Phytol. 154, 219-231. doi: 10.1046/j.1469-8137.2002.00367.x

Lilleskov, E. A., Hobbie, E. A., and Horton, T. R. (2011). Conservation of ectomycorrhizal fungi: exploring the linkages between functional and taxonomic responses to anthropogenic N deposition. Fungal Ecol. 4, 174-183. doi: 10.1016/j.funeco.2010.09.008

Liu, Y., Zuo, S., Xu, L., Zou, Y., and Song, W. (2012). Study on diversity of endophytic bacterial communities in seeds of hybrid maize and their parental lines. Arch. Microbiol. 194, 1001-1012. doi: 10.1007/s00203-012-0836-838

Marasco, R., Rolli, E., Ettoumi, B., Vigani, G., Mapelli, F., Borin, S., et al. (2012). A drought resistance-promoting microbiome is selected by root system under desert farming. PLoS ONE 7:e48479. doi: 10.1371/journal.pone.0048479

McCune, B., and Grace, J. B. (2002). Analysis of Ecological Communities. Gleneden Beach, OR: MjM Software Design.

McMurdie, P. J., and Holmes, S. (2013). phyloseq: an R package for reproducible interactive analysis and graphics of microbiome census data. PLoS ONE 8:e61217. doi: 10.1371/journal.pone.0061217

Moeller, H. V., Peay, K. G., and Fukami, T. (2014). Ectomycorrhizal fungal traits reflect environmental conditions along a coastal California edaphic gradient. Fems Microbiol. Ecol. 87, 797-806. doi: 10.1111/1574-6941.12265

Naveed, M., Mitter, B., Reichenauer, T. G., Wieczorek, K., and Sessitsch, A. (2014). Increased drought stress resilience of maize through endophytic colonization by Burkholderia phytofirmans PsJN and Enterobacter sp. FD17. Environ. Exp. Bot. 97, 30-39. doi: 10.1016/j.envexpbot.2013.09.014

O’Brien, H. E., Parrent, J. L., Jackson, J. A., Moncalvo, J. M., and Vilgalys, R. (2005). Fungal community analysis by large-scale sequencing of environmental samples. Appl. Environ. Microbiol. 71, 5544-5550. doi: 10.1128/AEM.71.9.55445550.2005

Oksanen, J., Blanchet, F. G., Kindt, R., Legendre, P., Minchin, P. R., O’Hara, R. B., et al. (2015). vegan: ommunity Ecology Package. R package version 2.3-0. Available at: http://CRAN.R-project.org/package=vegan

Oono, R., Lutzoni, F., Arnold, A. E., Kaye, L., U’Ren, J. M., May, G., et al. (2014). Genetic variation in horizontally transmitted fungal endophytes of pine needles reveals population structure in cryptic species. Am. J. Bot. 101, 1362-1374. doi: 10.3732/ajb.1400141

Pankievicz, V. C. S., do Amaral, F. P., Santos, K. F. D. N., Agtuca, B., Xu, Y., Schueller, M. J., et al. (2015). Robust biological nitrogen fixation in a model grass-bacterial association. Plant J. 81, 907-919. doi: 10.1111/tpj.12777

Peay, K. G., Kennedy, P. G., and Bruns, T. D. (2008). Fungal community ecology: a hybrid beast with a molecular master. Bioscience 58, 799-810. doi: 10.1641/B580907

Pianka, E. R. (1981). "Competition and niche theory," in Theoretical ecology principles and applications, ed. R. M. May (Hoboken, NJ: Blackwell Scientific), 167-196.

Pirttilä, A. M., Joensuu, P., Pospiech, H., Jalonen, J., and Hohtola, A. (2004). Bud endophytes of Scots pine produce adenine derivatives and other compounds that affect morphology and mitigate browning of callus cultures. Physiol. Plant. 121, 305-312. doi: 10.1111/j.0031-9317.2004.00330.x

Pirttilä, A. M., Laukkanen, H., Pospiech, H., Myllylä, R., and Hohtola, A. (2000). Detection of Intracellular Bacteria in the Buds of Scotch Pine (Pinus sylvestris
L.) by In Situ Hybridization. Appl. Environ. Microbiol. 66, 3073-3077. doi: 10.1128/aem.66.7.3073-3077.2000

Pirttilä, A. M., Pospiech, H., Laukkanen, H., Myllylä, R., and Hohtola, A. (2005). Seasonal variations in location and population structure of endophytes in buds of Scots pine. Tree Physiol. 25, 289-297. doi: 10.1093/treephys/ 25.3.289

Pirttilä, A. M., and Wäli, P. (2009). "Conifer endophytes," in Defensive Mutualism in Microbial Symbiosis, eds J. F. Jr. White and M. S. Torres (Boca Raton, FL: CRC Press), 235-246. doi: 10.1201/9781420069327.ch15

Pohjanen, J., Koskimäki, J. J., Sutela, S., Ardanov, P., Suorsa, M., Niemi, K., et al. (2014). Interaction with ectomycorrhizal fungi and endophytic Methylobacterium affects nutrient uptake and growth of pine seedlings in vitro. Tree Physiol. 34, 993-1005. doi: 10.1093/treephys/tpu062

Poole, A. M., Stouffer, D. B., and Tylianakis, J. M. (2012). 'Ecosystomics': ecology by sequencer. Trends Ecol. Evol. 27, 309-310. doi: 10.1016/j.tree.2012.03.008

Price, M. N., Dehal, P. S., and Arkin, A. P. (2009). FastTree: computing large minimum evolution trees with profiles instead of a distance matrix. Mol. Biol. Evol. 26, 1641-1650. doi: 10.1093/molbev/ msp077

R Core Team (2015). R: A Language and Environment for Statistical Computing. Vienna: R Foundation for Statistical Computing. Available at: http://www.R-pr oject.org/

Rastogi, G., Sbodio, A., Tech, J. J., Suslow, T. V., Coaker, G. L., and Leveau, J. H. J. (2012). Leaf microbiota in an agroecosystem: spatiotemporal variation in bacterial community composition on field-grown lettuce. ISME J. 6, 1812-1822. doi: 10.1038 /ismej.2012.32

Redford, A. J., Bowers, R. M., Knight, R., Linhart, Y., and Fierer, N. (2010). The ecology of the phyllosphere: geographic and phylogenetic variability in the distribution of bacteria on tree leaves. Environ. Microbiol. 12, 2885-2893. doi: 10.1111/j.1462-2920.2010.02258.x

Rhim, S.-L., Völksch, B., Gardan, L., Paulin, J.-P., Langlotz, C., Kim, W.-S., et al. (1999). Erwinia pyrifoliae, an Erwinia species different from Erwinia amylovora, causes a necrotic disease of Asian pear trees. Plant Pathol. 48, 514-520. doi: 10.1046/j.1365-3059.1999.00376.x

Richardson, D. M. (ed.). (2000). Ecology and Biogeography of Pinus. Cambridge: Cambridge University Press.

Rillig, M. C., Antonovics, J., Caruso, T., Lehmann, A., Powell, J. R., Veresoglou, S. D., et al. (2015). Interchange of entire communities: microbial community coalescence. Trends Ecol. Evol. 30, 470-476. doi: 10.1016/j.tree.2015.06.004

Rúa, M., Moore, B., Hergott, N., Van, L., Jackson, C., and Hoeksema, J. (2015). Ectomycorrhizal fungal communities and enzymatic activities vary across an ecotone between a forest and field. J. Fungi 1, 185-210. doi: 10.3390/ jof 1020185

Rúa, M. A., Umbanhowar, J., Hu, S., Burkey, K. O., and Mitchell, C. E. (2013). Elevated $\mathrm{CO}_{2}$ spurs reciprocal positive effects between a plant virus and an arbuscular mycorrhizal fungus. New Phytol. 199, 541-549. doi: $10.1111 /$ nph.12273

Ryberg, M., and Matheny, P. B. (2012). Asynchronous origins of ectomycorrhizal clades of Agaricales. Proc. R. Soc. B Biol. Sci. 279, 2003-2011. doi: 10.1098/rspb.2011.2428

Schardl, C. L., and Phillips, T. D. (1997). Protective Grass Endophytes: where are they from and where are they going? Plant Disease 81, 430-438. doi: 10.1094/PDIS.1997.81.5.430

Selosse, M.-A., Richard, F., He, X., and Simard, S. W. (2006). Mycorrhizal networks: des liaisons dangereuses? Trends Ecol. Evol. 21, 621-628. doi: 10.1016/j.tree.2006.07.003

Sevilla, M., Burris, R. H., Gunapala, N., and Kennedy, C. (2001). Comparison of benefit to sugarcane plant growth and 15N2 incorporation following inoculation of sterile plants with acetobacter diazotrophicus wild-type and nif- mutant strains. Mol. Plant Microbe Interact. 14, 358-366. doi: 10.1094/MPMI.2001.14.3.358.

Shen, S. Y., and Fulthorpe, R. (2015). Seasonal variation of bacterial endophytes in urban trees. Front. Microbiol. 6:427. doi: doi: 10.3389/fmicb.2015.00427

Shrestha, R., Koo, J.-H., Park, D.-H., Hwang, I.-G., Hur, J.-H., and Lim, C.-K. (2003). Erwinia pyrifoliae, a causal endemic pathogen of shoot blight of Asian pear tree in Korea. Plant Pathol. J. 19, 294-300. doi: 10.5423/PPJ.2003.19.6.294

Simpson, G. L. (2015). ggvegan: 'ggplot2' Plots for the 'vegan' Package. R package version $0.0-3$. 
Six, J., Frey, S. D., Thiet, R. K., and Batten, K. M. (2006). Bacterial and fungal contributions to carbon sequestration in agroecosystems. Soil Sci. Soc. Am. J. 70, 555-569. doi: 10.2136/sssaj2004.0347

Smith, M. D., Douhan, G., and Rizzo, D. (2007). Ectomycorrhizal community structure in a xeric Quercus woodland based on rDNA sequence analyzsis of sporocarps and pooled roots. New Phytol. 174, 847-863. doi: 10.1111/j.14698137.2007.02040.x

Smith, S. E., and Read, D. (2008). Mycorrhizal Symbiosis. London: Elsevier.

Suz, L. M., Barsoum, N., Benham, S., Dietrich, H.-P., Fetzer, K. D., Fischer, R., et al. (2014). Environmental drivers of ectomycorrhizal communities in Europe's temperate oak forests. Mol. Ecol. 23, 5628-5644. doi: 10.1111/mec. 12947

Tedersoo, L., May, T. W., and Smith, M. E. (2010). Ectomycorrhizal lifestyle in fungi: global diversity, distribution, and evolution of phylogenetic lineages. Mycorrhiza 20, 217-263. doi: 10.1007/s00572-009-0274-x

Upreti, R., and Thomas, P. (2015). Root-associated bacterial endophytes from Ralstonia solanacearum resistant and susceptible tomato cultivars and their pathogen antagonistic effects. Front. Microbiol. 6:255. doi: 10.3389/fmicb.2015.00255

Van Der Heijden, M. G. A., Bardgett, R. D., and Van Straalen, N. M. (2008). The unseen majority: soil microbes as drivers of plant diversity and productivity in terrestrial ecosystems. Ecol. Lett. 11, 296-310. doi: 10.1111/j.1461-0248.2007.01139.x

Van Der Putten, W. H. (2009). A multitrophic perspective on functioning and evolution of facilitation in plant communities. J. Ecol. 97, 1131-1138. doi: 10.1111/j.1365-2745.2009.01561.x

van der Putten, W. H., Bardgett, R. D., Bever, J. D., Bezemer, T. M., Casper, B. B., Fukami, T., et al. (2013). Plant-soil feedbacks: the past, the present and future challenges. J. Ecol. 101, 265-276. doi: 10.1111/1365-2745. 12054

Vetriani, C., Crespo-Medina, M., and Antunes, A. (2014). "The family salinisphaeraceae," in The Prokaryotes - Gammaproteobacteria, eds E. Rosenberg, E. F. Delong, S. Lory, E. Stackebrandt and F. Thompson (Berlin: Springer-Verlag), 591-596.

Vu, V. Q. (2011). ggbiplot: A ggplot2 Based Biplot. R package version 0.55. Available at: http://github.com/vqv/ggbiplot

Wagg, C., Jansa, J., Schmid, B., and van der Heijden, M. G. A. (2011). Belowground biodiversity effects of plant symbionts support aboveground productivity. Ecol. Lett. 14, 1001-1009. doi: 10.1111/j.1461-0248.2011.01666.x

Wardle, D. A., Bardgett, R. D., Klironomos, J. N., Setala, H., van der Putten, W. H., and Wall, D. H. (2004). Ecological linkages between aboveground and belowground biota. Science 304, 1629-1633. doi: 10.1126/science.1094875

Wickham, H. (2009). GGplot2: Elegant Graphics for Data Analysis. New York, NY: Springer.

Conflict of Interest Statement: The authors declare that the research was conducted in the absence of any commercial or financial relationships that could be construed as a potential conflict of interest.

Copyright (C) 2016 Rúa, Wilson, Steele, Munters, Hoeksema and Frank. This is an open-access article distributed under the terms of the Creative Commons Attribution License (CC BY). The use, distribution or reproduction in other forums is permitted, provided the original author(s) or licensor are credited and that the original publication in this journal is cited, in accordance with accepted academic practice. No use, distribution or reproduction is permitted which does not comply with these terms. 